\title{
Comparing effectiveness of virtual reality therapy and mindfulness- acceptance therapy on attention focus and social anxiety symptoms
}

\author{
Fazael Farnoush ${ }^{1}$, Moitaba Khodadadi ${ }^{2}$, Shahnaz Nouhi ${ }^{3}$ \\ 1 PhD of Psychology, Azad Islamic University Shahrood, Semnan, Iran \\ 2 Assistant Professor, Department of Psychology, Imam Hossein University, Tehran, Iran \\ 3 Assistant Professor Department of Psychology, Azad Islamic University Shahrood, Semnan, Iran
}

\begin{abstract}
Background: The purpose of this study was to evaluate effectiveness of virtual reality therapy and mindfulness-acceptance therapy on attention focus and social anxiety symptoms among social anxiety patients who referred to counseling centers of Tehran City.

Materials and methods: This semi-experimental study with pretest-posttest design was done on social anxiety patients. The sample consisted of 30 social anxiety patients who referred to counseling centers of Tehran City in summer and autumn 2018. Diagnosis of social anxiety disorder was based on clinical interview and social phobia inventory (SPIN). They and were selected through available sampling and then randomly assigned to two experimental groups (each 15 patients). Attention focus questionnaire and social phobia inventory (SPIN) was used for data gathering in the pre- and post-test. Two groups received either experience virtual reality therapy ( 8 sessions 20 minutes) or mindfulness-acceptance therapy ( 8 sessions 45 minutes).

Results: Both virtual reality therapy and mindfulness-acceptance therapy were effective on attention focus and social anxiety symptoms. Effectiveness of virtual reality therapy and mindfulness-acceptance therapy were significantly different in attention focus. In internal attention focus, virtual reality exposure therapy and in external attention focus, mindfulness-acceptance therapy were more effective. In social anxiety symptoms, two therapies were not different.

Conclusion: So according to our results, virtual reality therapy and mindfulness-acceptance therapy could use for improving attention focus and treating social anxiety symptoms.

Keywords: Virtual reality therapy, Mindfulness-acceptance therapy, Attention focus, Social anxiety symptoms.

Cited as: Farnoush F, Khodadadi M, Nouhi Sh. Comparing effectiveness of virtual reality therapy and mindfulness-acceptance therapy on attention focus and social anxiety symptoms. Medical Science Journal of Islamic Azad University, Tehran Medical Branch 2020; 30(3): 299-312.
\end{abstract}

Correspondence to: Mojtaba Khodadadi

Tel: +989127676557

E-mail: psy.farnoush@gmail.com

ORCID ID: 0000-0002-9076-2150

Received: 27 Apr 2019; Accepted: 31 Sep 2019 
مجله علوم يزشكى دانشعاه آزاد اسلامى

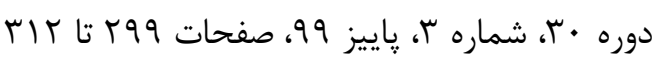

Original

Article

\title{
مقايسه اثربخشى درمان مبتنى بر فن آورى واقعيت مجازى و ذهن آكاهى - يذيرش بر كانون توجه و نشانههاى اختلال اضطراب اجتماعى
}

\author{
فاضل فرنوش'، مجتبى خدادادى ‘ ، شهناز نوحىى
}

' ل دكترى روانشناسى، دانشعاه آزاد اسلامى واحد شاهرود، سمنان، ايران

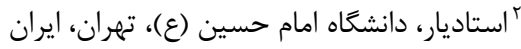

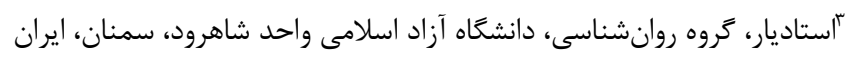
جـكيده

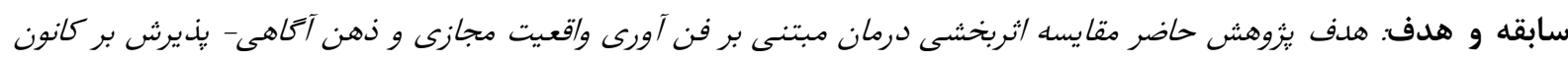

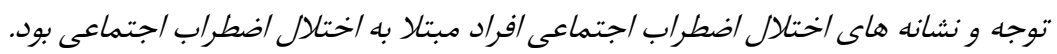

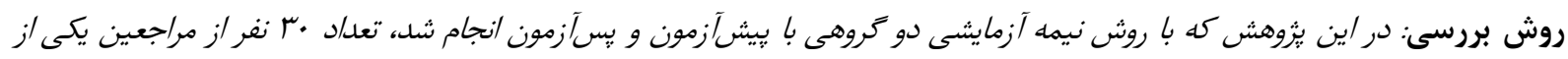

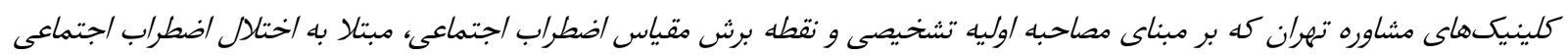

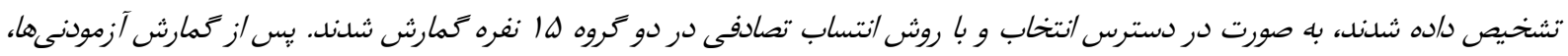

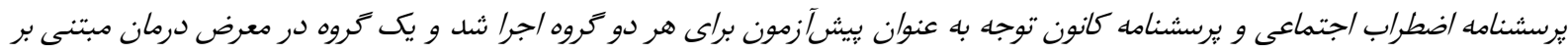

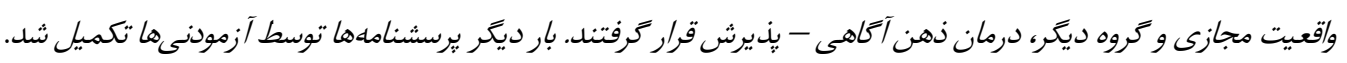

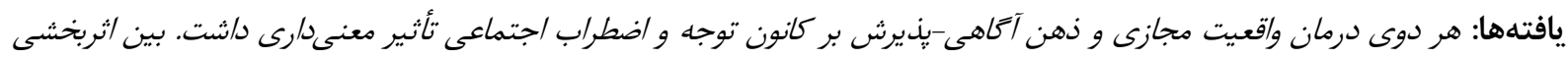

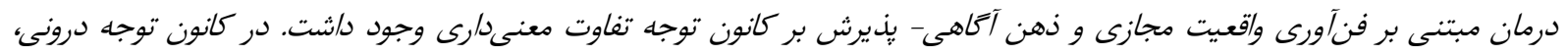

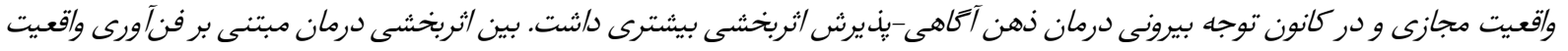

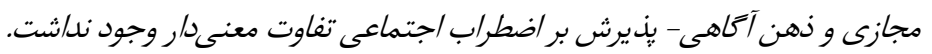

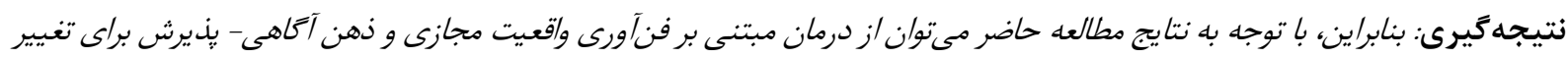

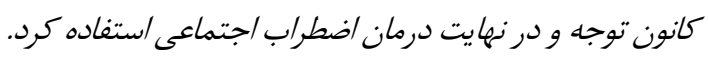

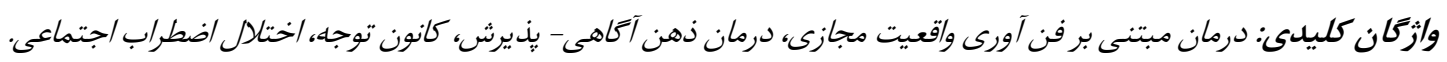

اضطراب شديدى را تجربه مى كنند. اينكونه افراد از موقعيتهـيـي

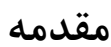

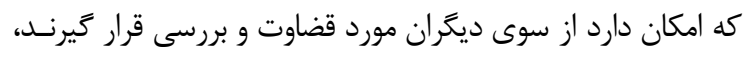

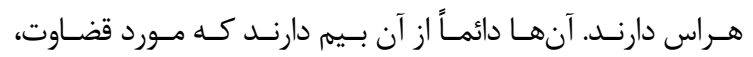

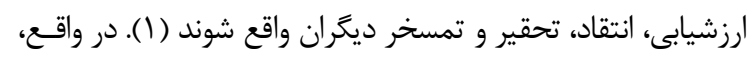

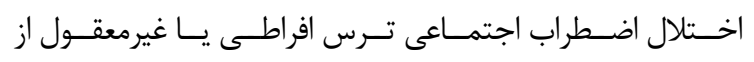

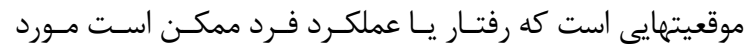

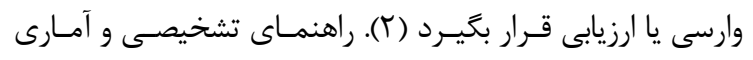

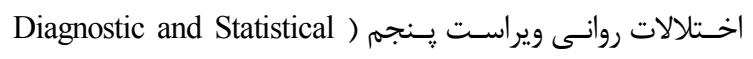
I I Manual of Mental Disorders, Fifth Edition

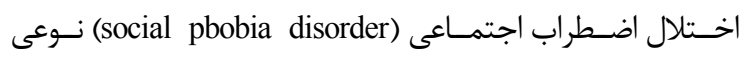

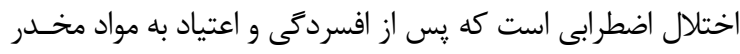

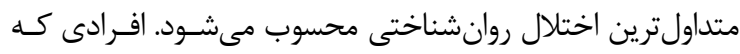

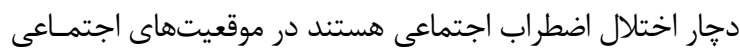

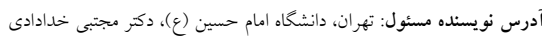
(email: : psy.farnoush@gmail.com) ORCID ID: 0000-0002-9076-2150

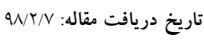

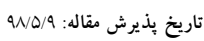


بهبودى اندك يا هيج بهبودى را نشان ندادهاند (با). لـذا نيـاز بــه

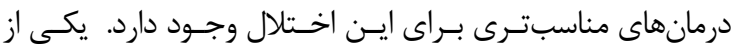

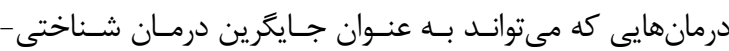
رفتارى براى اختلال اضطراب اجتمــاعى بـه حســاب آيـد، درمـان

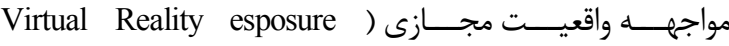

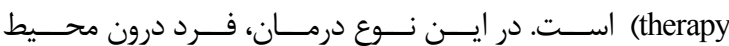
شبيهسازىشده رايانهاى غوطهور شده و بلطور ديدارى، شنيدارى، لامسهاى و يا با كمك ساير حواس خود با بيمارى يا مشـكل خــود ردو

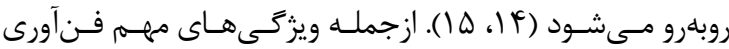
واقعيت مجازى مى توان به انعطاف يـذيرى بـالا، قابليـت سفارشىى شدن، بى خطر بودن و استفاده از تصاوير و جلوههاى بصرى جـذاب اشاره كرد و ازآنجاكه استفاده از تصويرسازى نقش مهمدى بـى در روان درمانى دارد (ع)، IV)، واقعيت مجازى با درگيـر كـردن بيمـار در

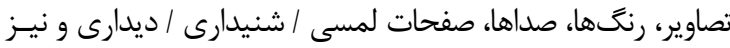

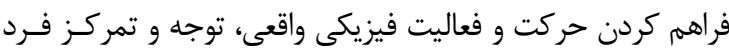

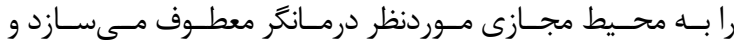

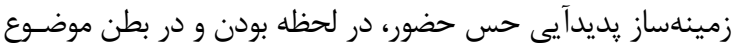

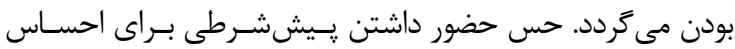
هيجانات مختلف در جريان درمان است. براى مثال بيمار مىتوانـد بهراحتى اضطراب را در محيط مجازى تجربـهـ كنــد و پاســخهـاى

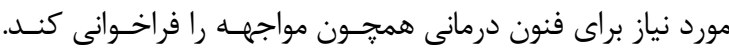
همجنين، در اين رويكرد بهجاى آنكه از مواجهه كلامسى بـه شـيوه حساسيتزدايى تدريجى استفاده شود، از مواجهه مجازى كـه فـرد

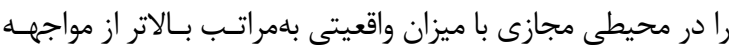
كلامى (تجسمى) بــه شـيوه حساسـيتزدايسى تـدريجى و مشـابه موقعيت واقعى قرار خواهد داد استفاده مسىشـود ( IV IV). يكىى ).

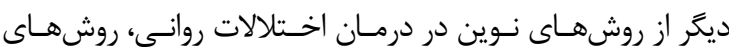
موسوم به موج سوم درمانهاى شناختى رفتارى اسـت. مـداخلات

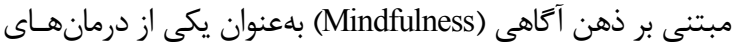

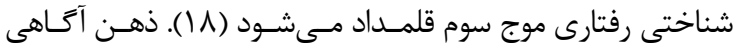

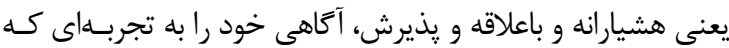

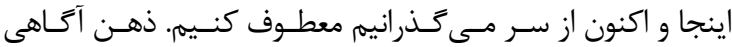
جنبههاى زيادى دارد، در لحظه اكنون زندگى كنيه، بهجاى غـرق

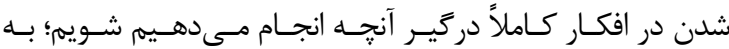

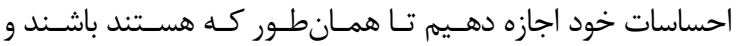
بهجاى كنترل كردنشان اجـازه بـدهيم تـا بياينـد و برونـد. وقتى

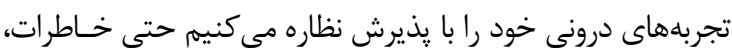

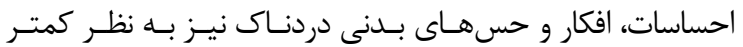

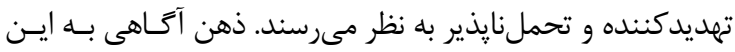

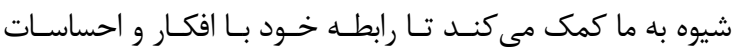

ماهه اختلال اضطراب اجتماعى در مردم آمريكا را حدود V درصـد

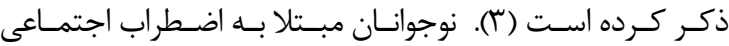

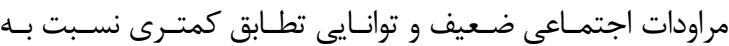
همسالان خود دارند و در مواجهه با انتظارات دوران بزرگسالى بـا

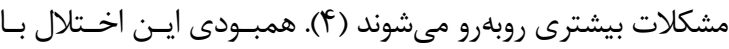

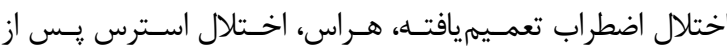
سانحه، افسردگى و مصرف الكل و مواد مخــدر اسـت (ه). بنـابراين

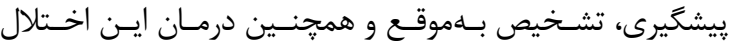

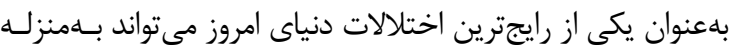

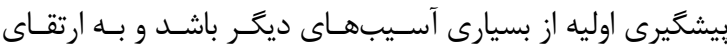

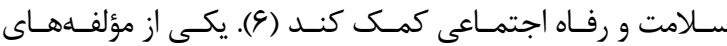
شناختى كه به نظر مىرسد با اختلال اضطراب اجتمـاعى مـرتبط ريط

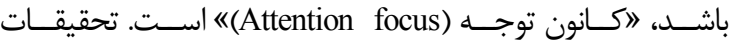

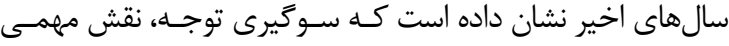

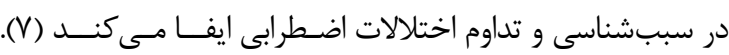

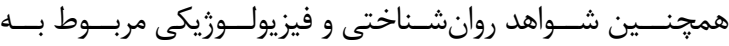

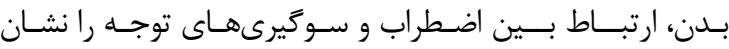

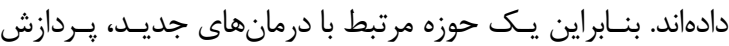
توجه است (^). مدل كاركرد اجرايى خـود نظـم بخــش، كنتــرل

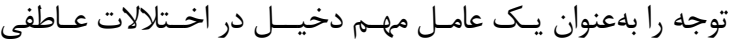

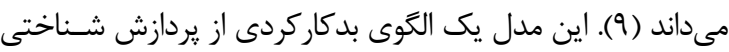
موسوم به سـندرم شـناختى - تـوجهى را مشـخص مسى كنـد كـهـ شامل توجه معطوف بـه خـود نامنعطف، افكار درجامانده (نشـخوار

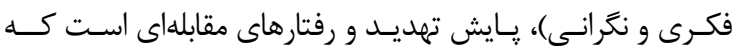

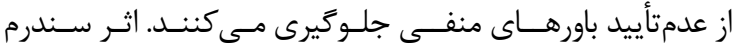
شناختى - توجهى، تــاوم توجــه معطوف به خود است كـهـ از ايـنـ

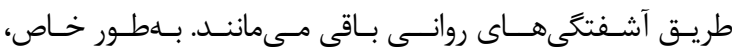

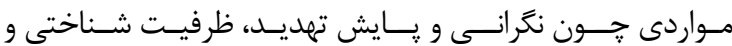
توجهى را كاهش مى كدهند. ازاينرو افراد از توجه به ســاير منــابع

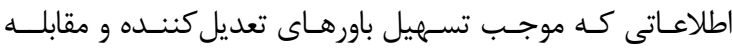

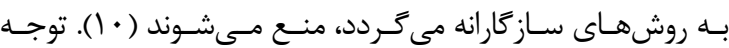
معطوف به خود يكى از ييشبينى كنـــدهـــاى اخـتلال اضـطراب

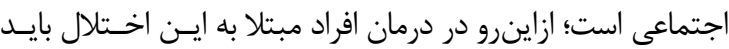
بهطور خاص توجه معطوف به خـود را مـورد توجـهـ قــرارداد (1).

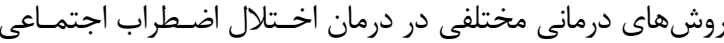
ستفاده مىشود. يكى از روشهاى درمانى كه بــراى ايسن اخـتلال

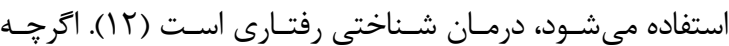

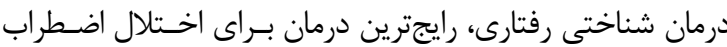

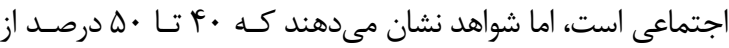
مبتلايان به اضطراب اجتماعى كه تحت اين درمان قرارگرفتـهانـد، 
فراشناختى مثبت و منفى، نظـارت شـناختى، ســندرم شـناختى -

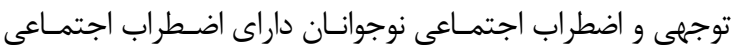

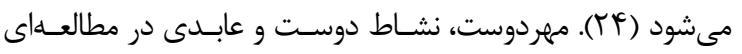

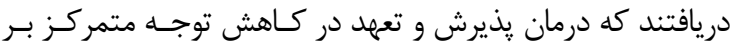

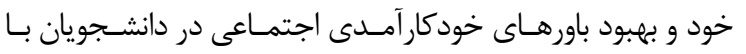

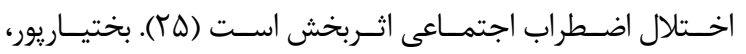
حيدرى و على يورخدادادى در يزوهشـى دريافتنـد كـه سـوَيرى

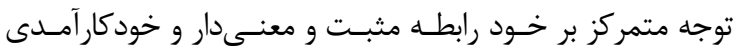

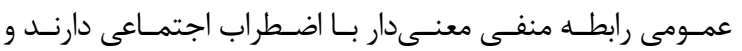

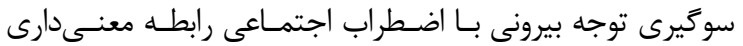

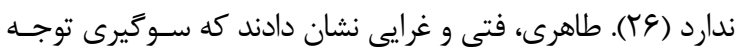

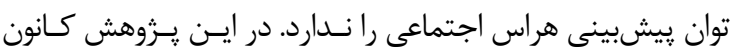

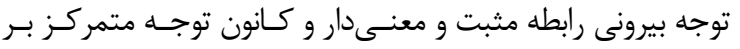

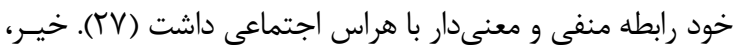

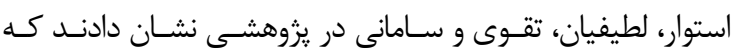
اضطراب اجتماعى همبستخى معنى دارى با توجه متمركز بــر خــود

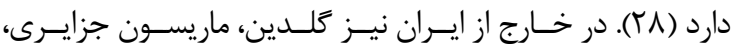

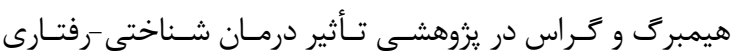
كروهى (Cognitive behavioral group therapy) و ذهـن آخـاهى

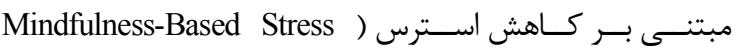
(Reduction

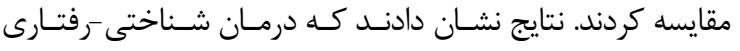

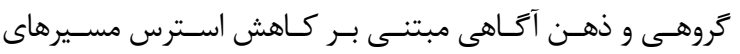
مشابهى را طى مى كنند كه نشاندهنده كاهش اضطراب اجتماعى ده إنى و افزايش تغيير در شيوه تفكر و ذهن آتـاهى اسـت (9 ( ). كـيم و

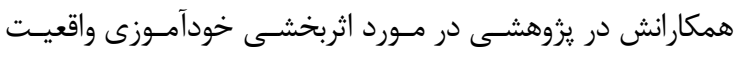

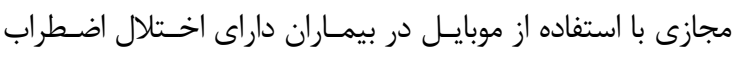

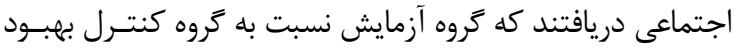

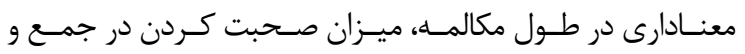

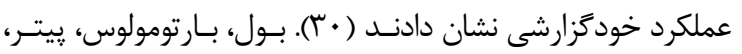

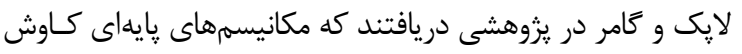

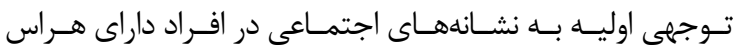

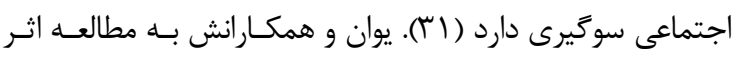
محيطهاى مجـازى بـر خــ (Online virtual environments) در برنامه موسوم بـهـ زنـدكى دوم (Second Life) در درمــان اخـتلال

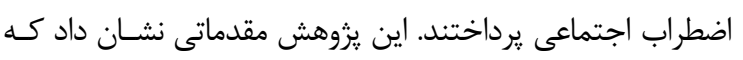

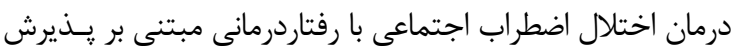

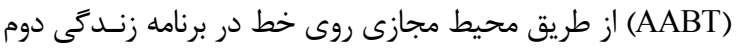

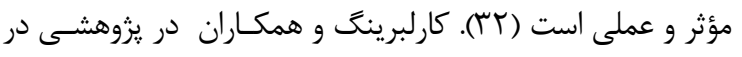

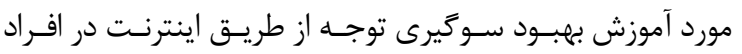

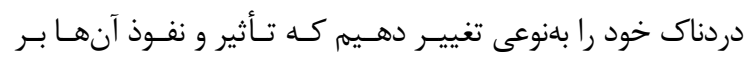

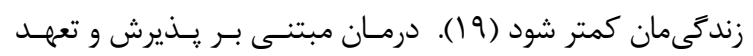
ACT كـه بــاختصـار (Acceptance and commitment therapy) ناميده مىشود، يكى از رفتاردرمانىهاى مبتــى بـر ذهـن آحـاهى

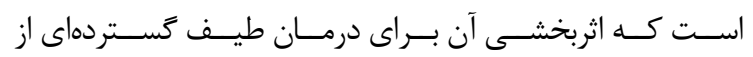

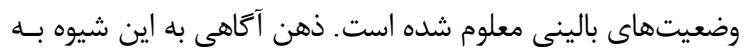

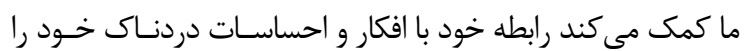

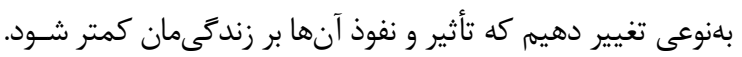
با اين توصيف مداخلات درمان مبتنى بر يذيرش و تعهــد يَيرامـون

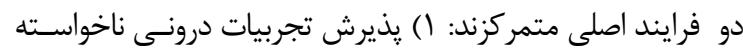

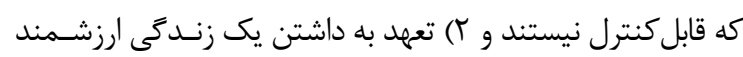

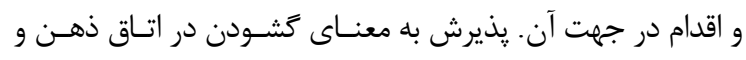

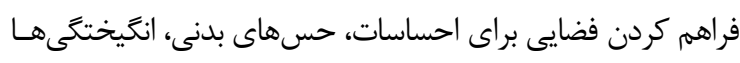
و هيجانهاى دردناك است. ما در اين حالت دست از دركيــى بـ بـا

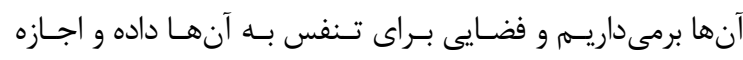

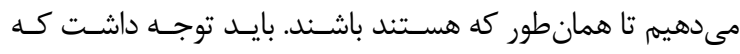

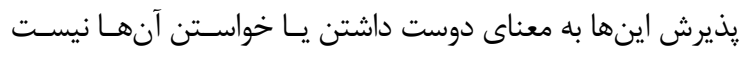

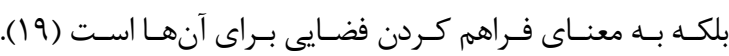
يزوهشهايى در خصوص درمـان اخـتلال اضـطراب اجتمــاعى در ايران و خارج از كشور صورت گرفته است. ازجمله، ناظمى، نجفـى درى

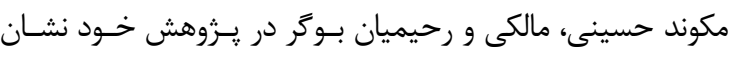

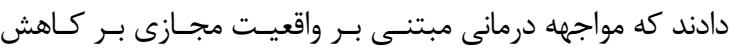

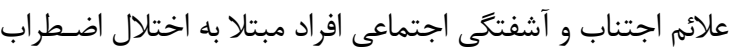

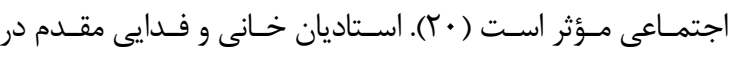

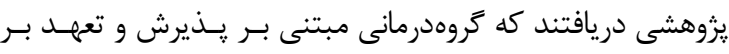

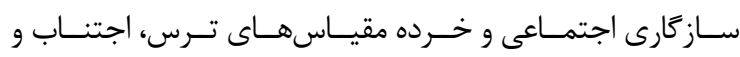
فيزيولوزى و نمـره هـراس اجتمـاعى تـأثير دارد (Iآ). سـليمانى، احمدى و محمدى در يكى مطالعـه مـرورى دريافتنـد كـه درمـان

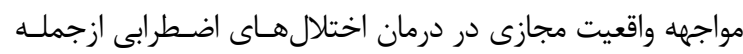
هراس خاص و اجتماعى، اختلال استرس يـس از ضـربه، اخـتلال

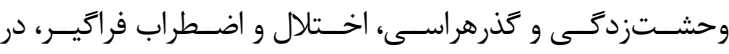

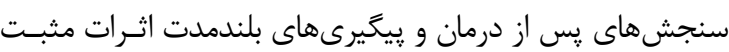

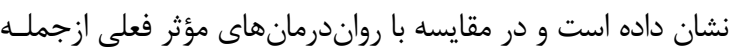
درمان مواجهه زنده و رفتاردرمانى - شناختى، اثرات مثبـت مشـابه

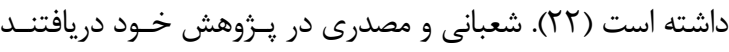

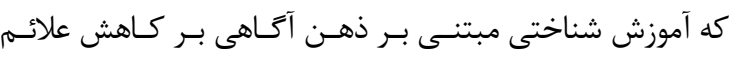
اختلال اضطراب اجتماعى دانش آموزان دختر مقطع متوسطه اول اثربخش است (Tr). در يزوهشى ديخـر، شـيخان، محمـدخانى و

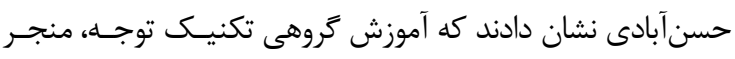

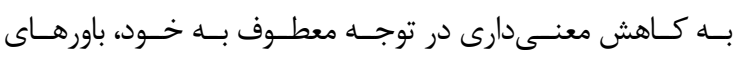




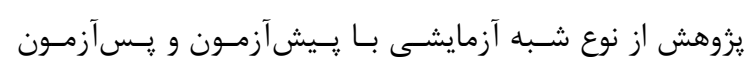

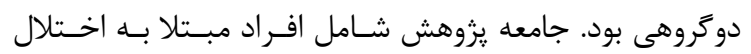

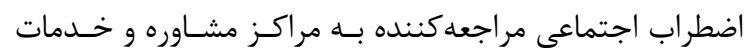

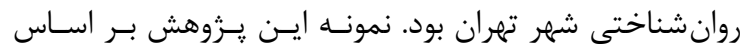

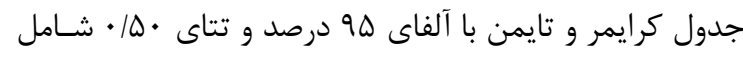

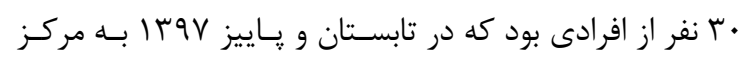

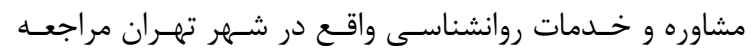

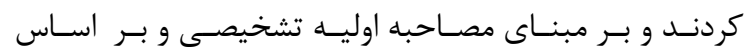

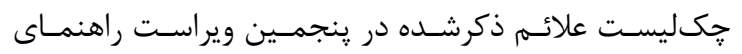

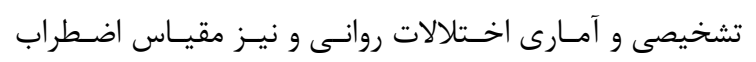

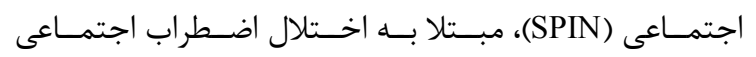

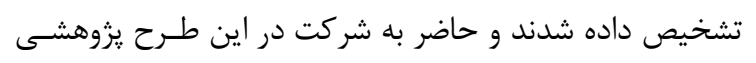

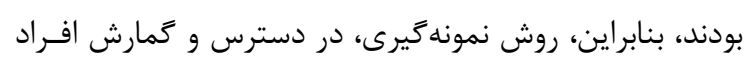

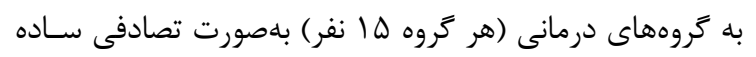
بود. معيارهاى ورود شامل موارد زير بود: إ- ابـتلا بــه اخـتلال

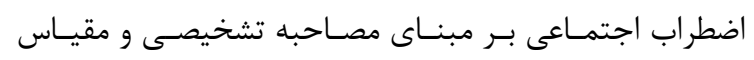

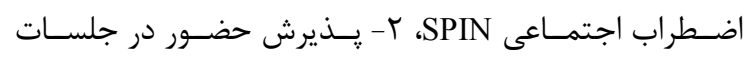

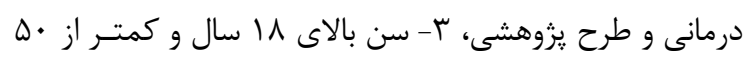

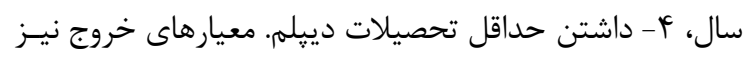

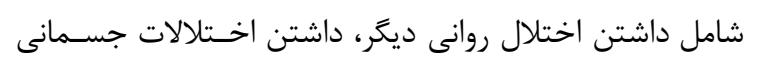

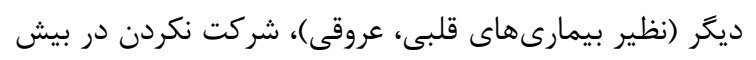

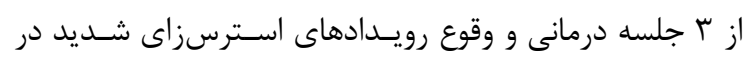
زندكَى (مثل طلاق يا فوت اقوام درجه وريك) بود.

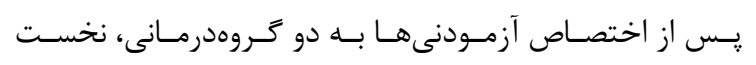

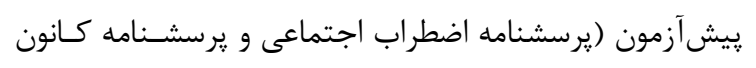

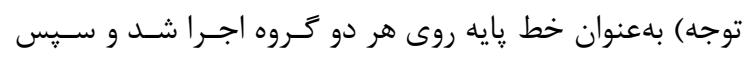

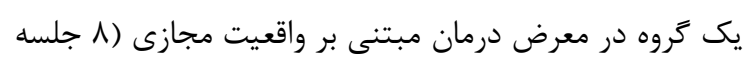

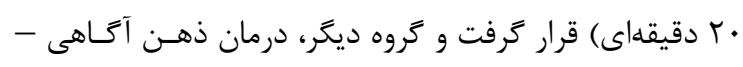

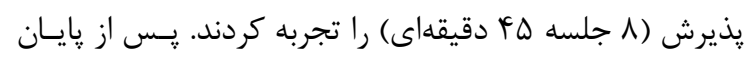

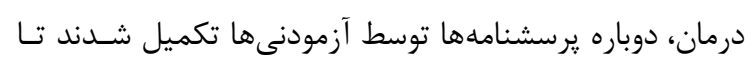
اثربخشى روشهاى درمانى موردسنجش و تفسير قرار كيرد.

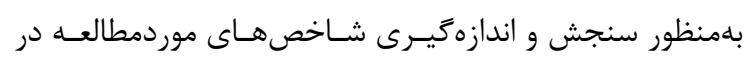
يزوهش حاضر از روشها و ابزارهاى زير استفاده شد:

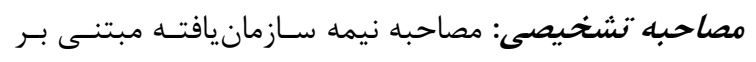

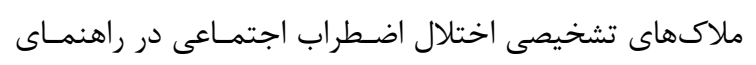

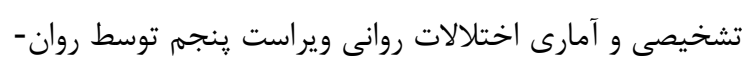
درمانغر بالينى.

يرسشنامه كانون توجه: ايـن برسشــامه كـهـ توسـط وودى،

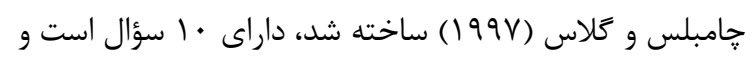

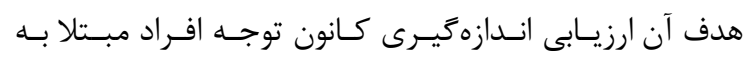

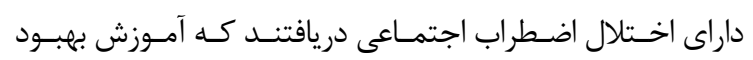

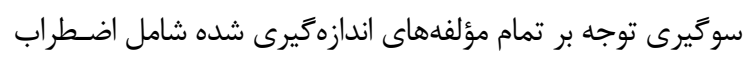

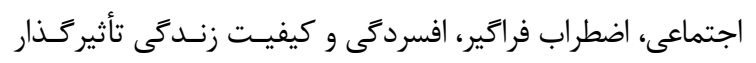

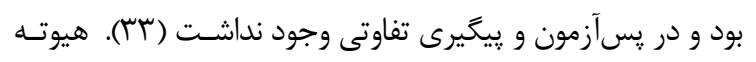

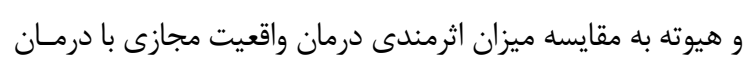

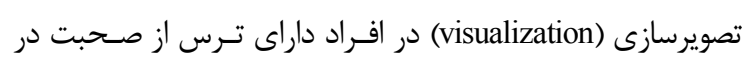

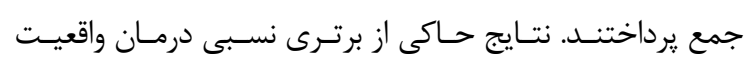

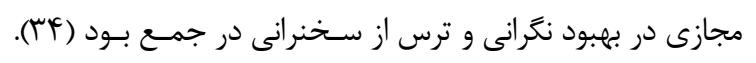

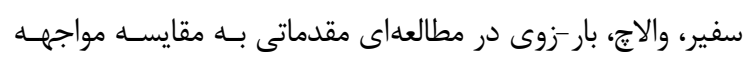

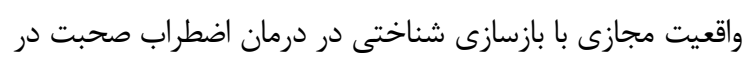

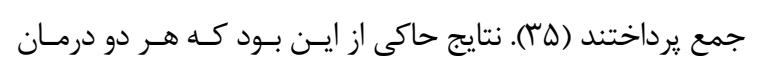

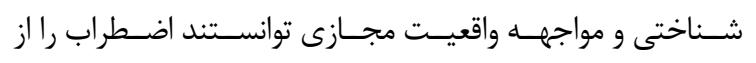

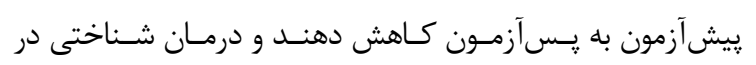

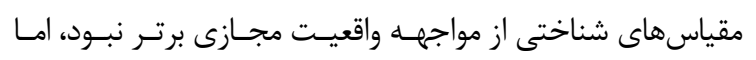

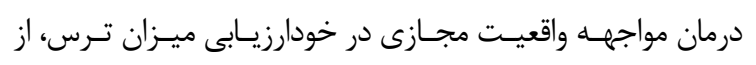

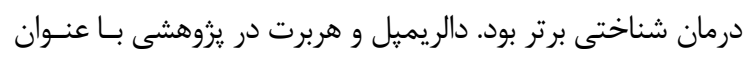

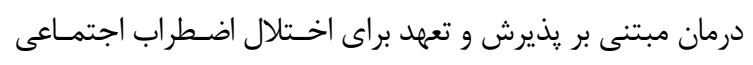

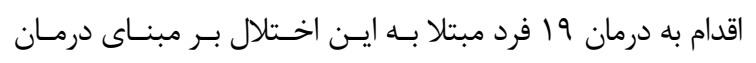

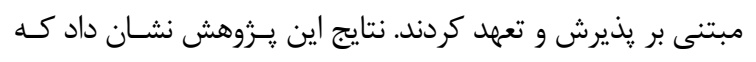

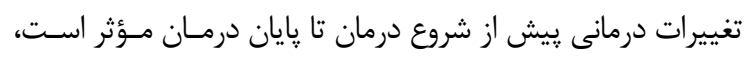

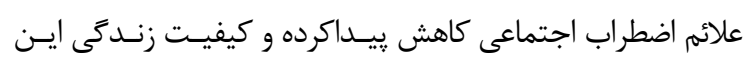

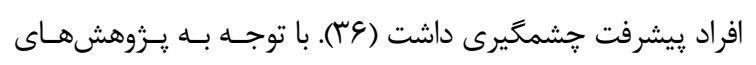
ذكرشده روش هاى مختلفى به درمان موضوعات مربوط بـ به اخـتـال

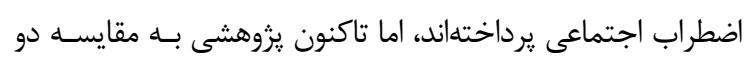

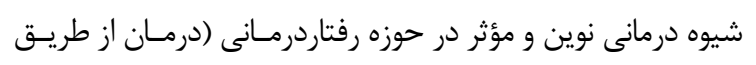

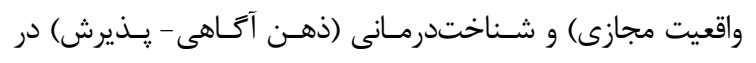

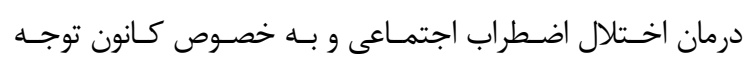

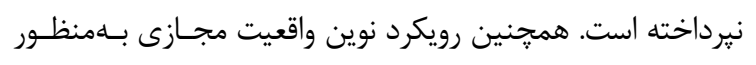

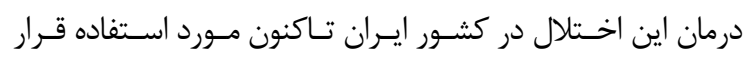

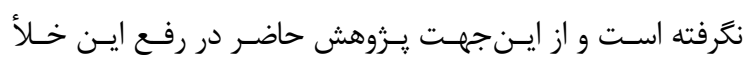

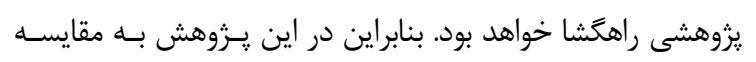

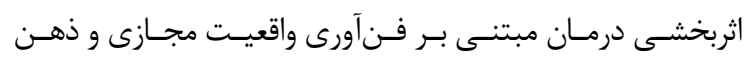

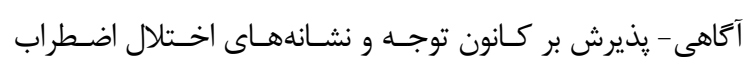
اجتماعى ثرداخته شد.

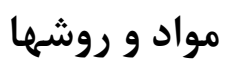

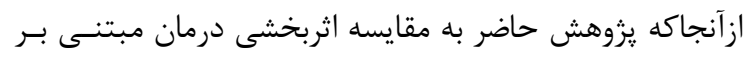

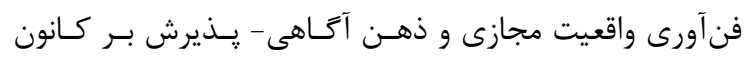

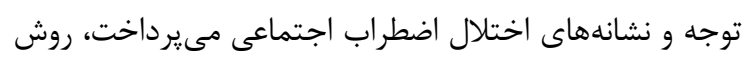


جدول ا. خلاصه يروتكل درمانى مبتنى بر واقعيت مجـازى نـورث،

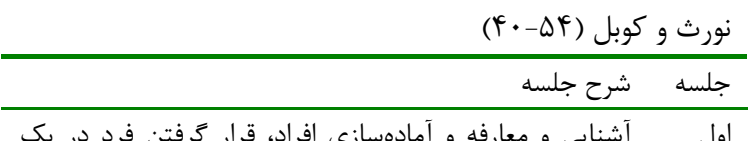

اول آشنايى و معارفه و آمادهسازى افراد، قرار كرفتن فرد در يك

مكان عمومى (ف مانى

(فروشگاه و ديده شدن و موردتوجه قرار كرفتن مداوم توسط

افراد ديكر حاضر در آن موقعيت)

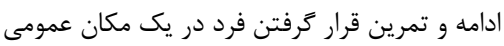

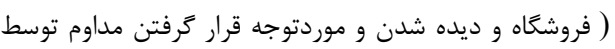

افراد ديكر حاضر در آن موقعيت)

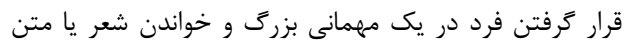

براى حاضرين

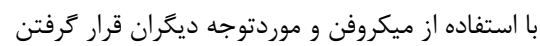

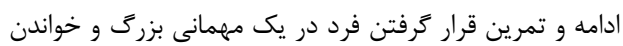
شعر يا متن براى حاضرين

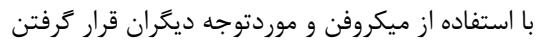

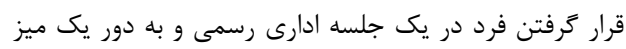

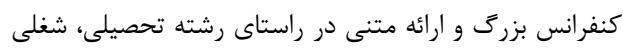

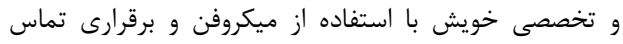
جشمى با حاضرين ادامه و تمرين قرار خرفتن فرد در يكى جلسه ادارى رسمى و به يه

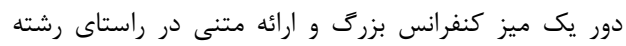

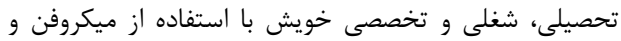
برقرارى تماس جشمى با حاضرين تُعنى شركت فرد در يك سمينار و همايش با تعداد شركت جمت كنندكان زياد خواندن متنى كه از قبل تهيه كرد دهد با استفاده از ميكروفن،

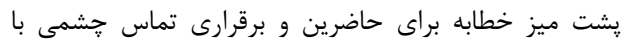
افراد حاضر

ادامه و تمرين شركت فرد در يك سمينار و همايش با تعداد

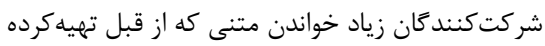

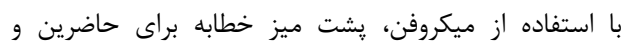

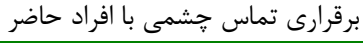

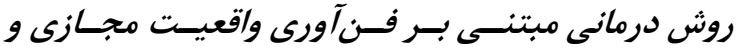
نرمافزار هراس اجتماعى: واقعيت مجازى فناورى اسـت كـهـ

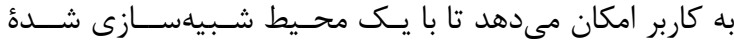

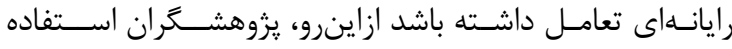

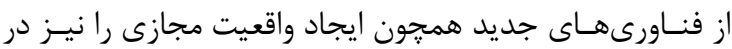

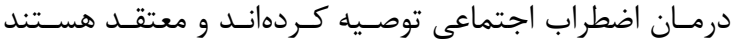
در واقعيت مجازى، مىتوان با كمك كامييوتر، دنياى سهبعـدى

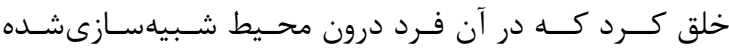

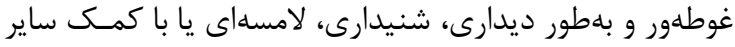
حواس خود با بيمارى يا مشكل خود مواجه مىشود. اين روش

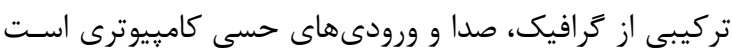

اضطراب اجتمـاعى در تعـاملات اجتمـاعى از دو بعـد مختلـف (كانون توجه متمركز بر خود، كانون توجه بيرونى) اسـت (YV)

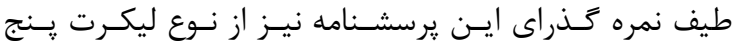

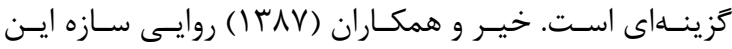

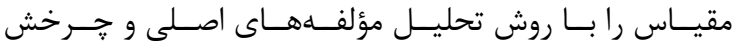

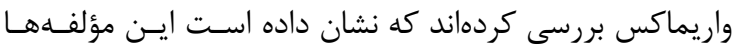

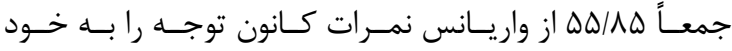

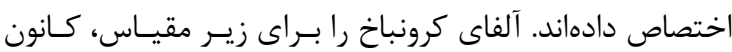

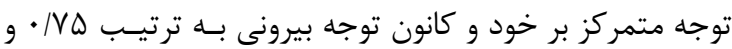

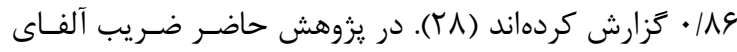
كرونباخ 1AK| • به دست آمد. مقياس اضطراب اجتماعى SPIN : ايـن مقيـاس نخسـتين

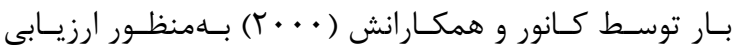

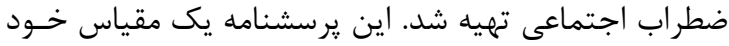

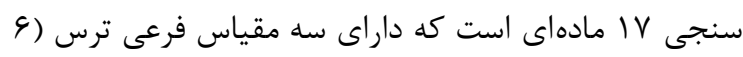

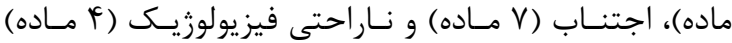

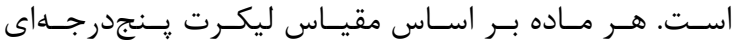

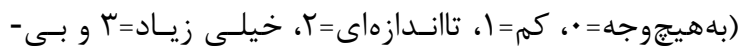

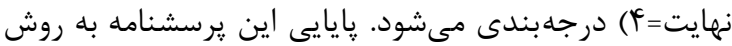

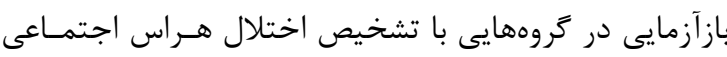

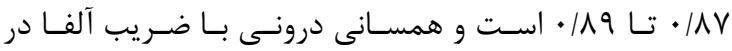

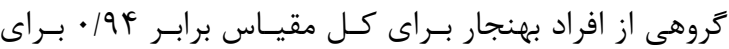

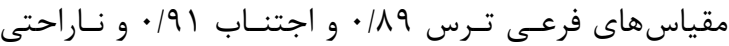

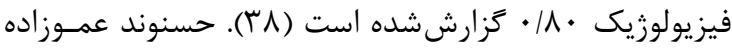

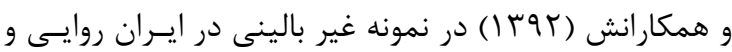

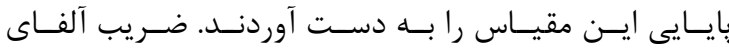

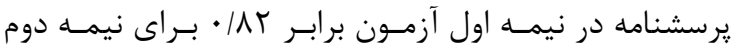

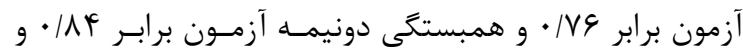

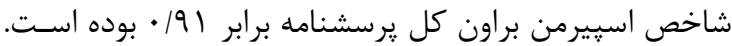

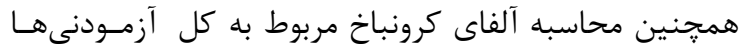

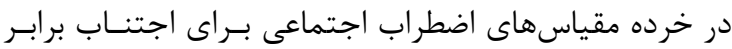

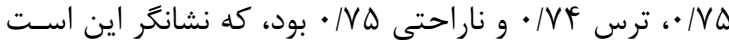
كه پِايايى محاسبه شده رضايتبخش اسـت. اعتبـار همخـراى

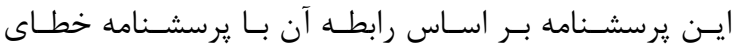
شناختى له//•، نمرات مقياس درجهابندى حرمت خود

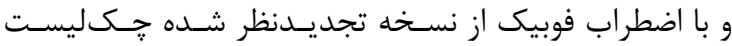

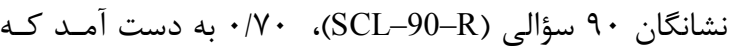

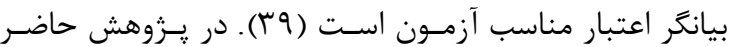

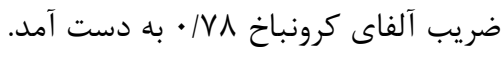


رنج فرد در جهار وضعيت كه در موقعيتهاى اجتمـاعى انجـام

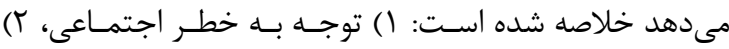

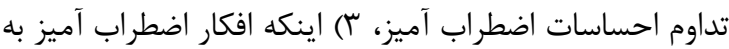

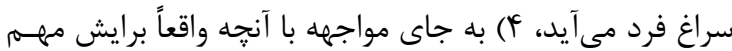

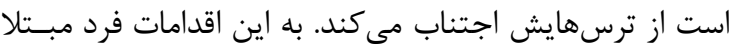

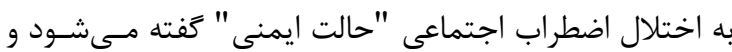

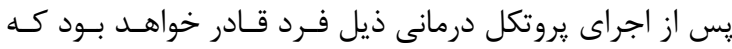

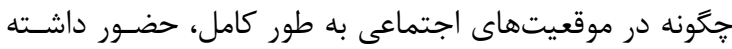

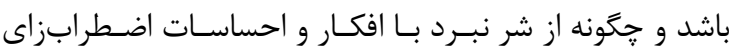
خود رها شود و پِس از آن روى آنجه برايش مهـهم اسـت يعنسى ارزشها و اهدافش متمركز شود (1) أ).

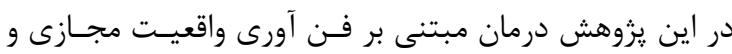

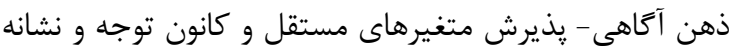
هاى اختلال اضطراب اجتماعى متغير وابسته بودند.

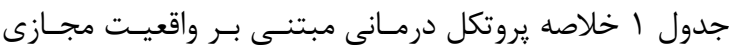
نورث، نورث و كوبل و جدول r خلاصه يروتكل درمانى مبتنس

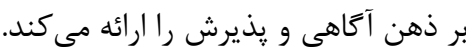
براى تحليل دادها از شاخصهاى آمار توصيفى نظير فراوانىى،

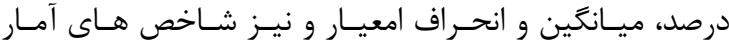

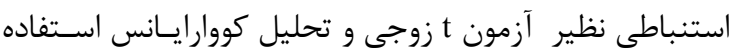
شد. ه•|•p معنى دار در نظر ترفته شد.

\section{يافتهها}

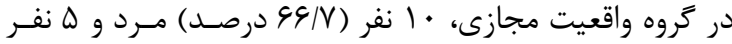

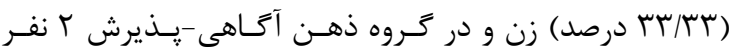

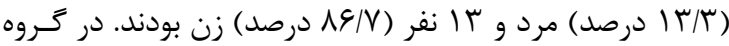

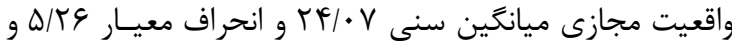

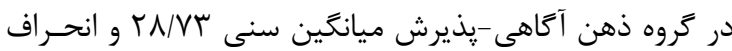

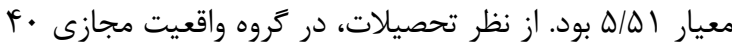

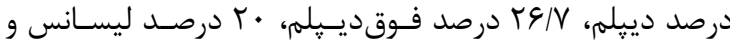

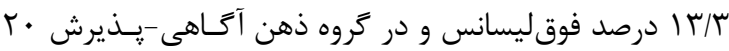

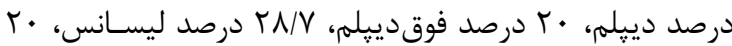
درصد فوقليسانس و س/ آ درصد دكترى بودند.

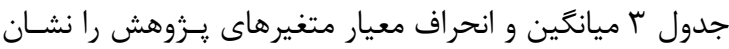
مى دهد. همجنين، اين جدول نشان مى دهد كه آزمون t زوجى

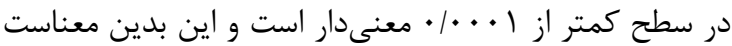

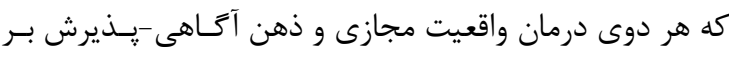

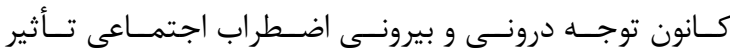

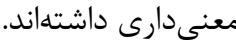

كه جهانى كـامِيوترى را شكل مى دهد كه در آن فرد مىتواند

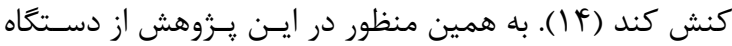

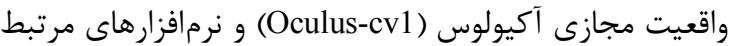
با هراس اجتماعى براى مواجهه استفاده شد. مـدتزمــان ايسن إنـ

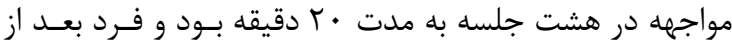
قرار دادن هدست واقعيت مجازى شروع به تعامـل مسـتقيم بــاــا افراد حاضر در يك جلسه سخنرانى كـرد و متنسى را بـهـعنـوان يكى سخنرانى، ارائه داد.

جدول r. خلاصه يروتكل درمانى مبتنى بر ذهن آكَاهى و پـذيرش (f) $-4 r, r q)$

\begin{tabular}{rrr}
\hline & اولسه \\
\hline
\end{tabular}

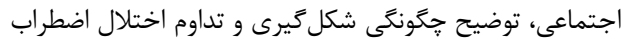

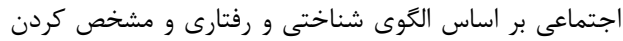
تكليف خانكى بر اساس الكوى شناختى و و رفتارى

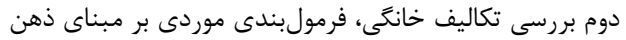

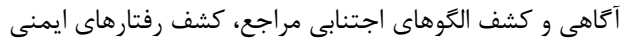

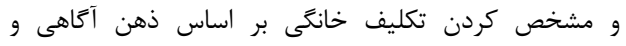
الكوهاى اجتنابى و رفتارهاى ايمنى كردي تكليف

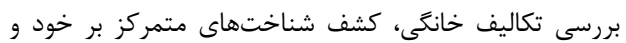
كشف شناختهاى آميخته با افكار اضطرابى كئى

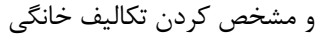

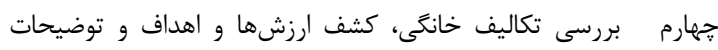

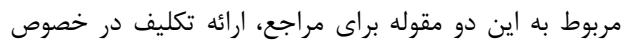

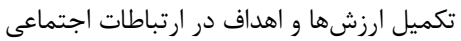

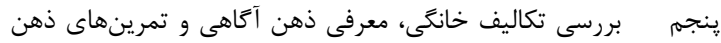

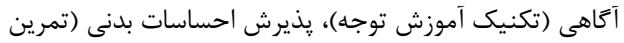

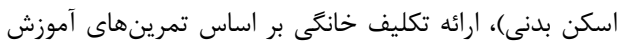
دادهشه ششم بررسى تكاليف خانكى، آموزش جدا شدن از افكار اضطراب زا

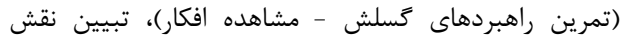

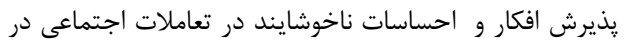

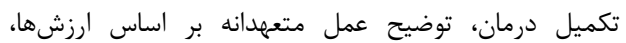

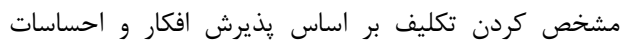

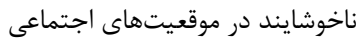
هفتم بررسى تكاليف ارائهشه در رويارويى موقعيتهاى اجتى اجتماعى و يذيرش احساسات و افكار ناخوشايند در حين مواجهه، ارائه درائه

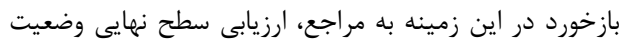

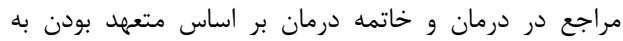

ارزشها

روش درمانى مبتنى بر ذهن آكاهى و يذيرش: براى انجـام

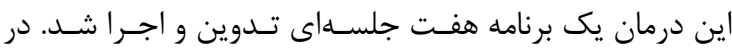

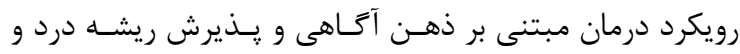




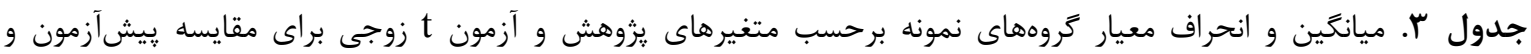

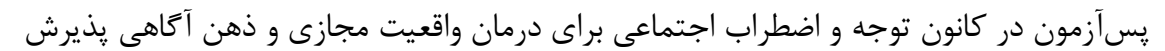

\begin{tabular}{|c|c|c|c|c|c|c|c|}
\hline \multirow[t]{2}{*}{ سطح معنى دارى } & \multirow[t]{2}{*}{ آزمون t } & \multicolumn{2}{|c|}{ مِسِآزمون } & \multicolumn{2}{|c|}{ ي بيش آزمون } & \multirow[t]{2}{*}{ متغير } & \multirow[t]{2}{*}{ كروه } \\
\hline & & انحراف استاندارد & ميانكَين & انحراف استاندارد & ميانكَين & & \\
\hline$<\cdot 1 \cdot \cdots \cdot \mid$ & $I T / \Delta Q$ & $r / l$ & $\mid r / / r$ & $1 / \Lambda r$ & $19 / \cdot V$ & كانون توجه درونى & واقعيت \\
\hline$<\cdot|\cdot \cdots|$ & $-p / q$. & 1/99 & $\mid r / 4 V$ & $1 / 99$ & $11 / r$ & كانون توجه بيرونى & مجازى \\
\hline$<\cdot|\cdot \cdots|$ & 1.199 & $V / 91$ & $\kappa r / 4$. & D/IT & $s \pi / r$. & اضطراب اجتماعى & \\
\hline$<\cdot \mid \cdot \cdots)$ & $r \cdot \mid \Delta \Lambda$ & $1 / 19$ & $q / 4 V$ & T/Tr & IN/TV & كانون توجه درونى & ذهن \\
\hline$<\cdot 1 \cdot \cdots 1$ & $-11 / 9 \Delta$ & $r / T$ & $1 \Delta / \Delta r$ & 1/9. & $1 \cdot 11$ & كانون توجه بيرونى & آكَاهى \\
\hline$<\cdot|\cdot \cdots|$ & IV/A. & $\Delta / \Gamma \varphi$ & $F \Delta / T V$ & $\Delta / \Delta \varphi$ & $9 \Delta / r r$ & اضطراب اجتماعى كل & ل \\
\hline
\end{tabular}

جدول F. آزمون كالموكراف اسميرنوف براى بررسى نرمال بودن دادهها

\begin{tabular}{|c|c|c|c|c|c|}
\hline \multicolumn{2}{|c|}{ بِ آزمون } & \multicolumn{2}{|c|}{ يِيشآزمون } & \multirow[t]{2}{*}{ متغير } & \multirow[t]{2}{*}{ كروه } \\
\hline سطح معنادارى & Z آماره Z & سطح معنادارى & آماره Z & & \\
\hline$\cdot / 9 V$ &.$/ 49$ & $.19 \mathrm{~V}$ & $\cdot / V T$ & كانون توجه درونى & واقعيت \\
\hline$\cdot \mid \Delta F$ & $\cdot / \Lambda$ & .19. & $\cdot \mid \Delta V$ & كانون توجه بيرونى & مجازى \\
\hline . $/ \Lambda r$ & . & $\cdot \mid \Delta \Lambda$ & $\cdot / \mathrm{VA}$ & اضطراب اجتماعى & \\
\hline$\cdot / D F$ & $\cdot / 1$ & $\cdot / 19$ & $\cdot \mid \Delta \Lambda$ & كانون توجه درونى & ذهن آكاهى \\
\hline .19. & $\cdot / \Delta V$ &. $\mid 94$ & $\cdot / \mathrm{V}^{\mathrm{F}}$ & كانون توجه بيرونى & يذيرش \\
\hline .194 & $\cdot \mid \Delta F$ & .199 & $\cdot / 4 \Delta$ & اضطراب اجتماعى & \\
\hline
\end{tabular}

جدول هـ آزمون باكس و لون براى بررسى برابرى ماتريس كوواريانس و همخَى واريانسها

\begin{tabular}{|c|c|c|c|c|c|c|}
\hline p-value & Df2 & Df1 & $\mathrm{F}$ & M & متغير & نوع آزمون \\
\hline$\cdot \pi \Delta$ & $\|f\| r$. & $r$ & $1 / \pi \Lambda$ & $f / q q$ & & آزمون باكس \\
\hline .1 .9 & $r \Lambda$ & 1 & $r / q 4$ & & كانون توجه درونى & آزمون لون \\
\hline $.19 \mathrm{~V}$ & $r \Lambda$ & 1 & .119 & & كانون توجه بيرونى & \\
\hline$\cdot \mid \Delta F$ & rᄉ & 1 & $\cdot \pi \Delta$ & & خودكارآهدى اجتماعى & \\
\hline
\end{tabular}

جدول צ. نتايج آزمون هاى جندَّانه براى بررسى براى مقايسه اثربخشى درمان مبتنى بر فن آورى واقعيت مجازى و ذهن آكاهى -

\begin{tabular}{|c|c|c|c|c|c|c|c|c|}
\hline & & & & & & & \multicolumn{2}{|c|}{ يذيرش بر كانون توجه } \\
\hline توان آزمون & مجذور اتا & $\mathrm{P}$ & خط Df & فرضى Df & $\mathrm{F}$ & ارزش - ار & آزمون & اثرات \\
\hline $1 / \cdot$ & .199 & $\cdot|\cdots|$ & $r \Delta$ & $r$ & TV/G9 & .1919 & اثر پيلايى & 5روه \\
\hline $1 / \cdot \cdot$ & .199 & $\cdot|\cdots|$ & $r \Delta$ & r & TV/GG & $\cdot \pi 11$ & لامبداى ويلكز & \\
\hline $1 / \cdot$ & .199 & $.1 \ldots 1$ & $r \Delta$ & r & $T V / 99$ & t/TIT & اثر هتلينگ & \\
\hline $1 / \cdot$ & .199 & $.1 \cdots 1$ & $r \Delta$ & r & $T V / 99$ & T/TIT & بزركترين ريشه روى & \\
\hline
\end{tabular}

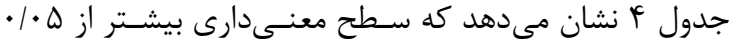

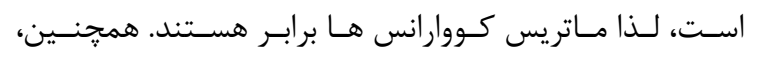
وار يانس ها همخن هستند.

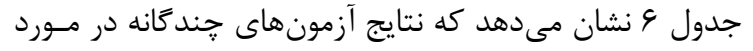

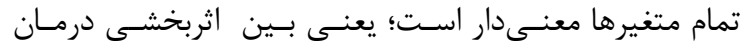

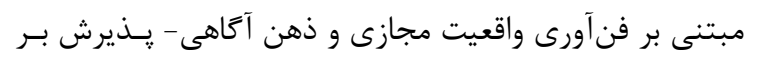

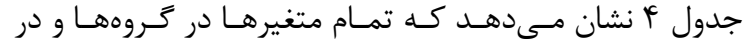
يشيشآزمون و يسآزمون داراى توزيع نرمال است.

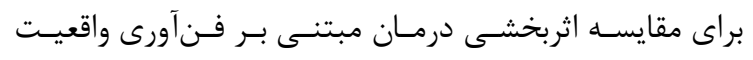

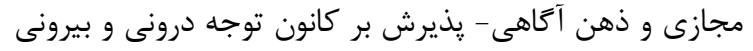
از تحليل كوواريانس دوطرفه استفاده شد. 
جدول V. اثرات بين آزمودنى براى بررسى براى مقايسه اثربخشى درمان مبتنى بر فنآورى واقعيت مجازى و ذهن آكاهى-

\begin{tabular}{|c|c|c|c|c|c|c|c|c|}
\hline & & & & & & & \multicolumn{2}{|c|}{ يذيرش بر كانون توجه } \\
\hline توان آزمون & اتا & $\mathrm{P}$ & $\mathrm{F}$ & ميانكين مجذور & $\mathrm{df}$ & مجموع مجذور & متغير وابسته & \\
\hline $1 / \cdot$ & $\cdot 109$ & $<\cdot \mid \cdots \cdot 1$ & rG/VT & VEIAFV & 1 & V\&/FqV & كانون توجه درونى & كروه \\
\hline .199 & $\cdot / f F$ & $<\cdot 1 \cdots \cdot 1$ & $r \cdot / \Delta r$ & $F V / V \Delta q$ & 1 & $F V / V \Delta q$ & كانون توجه بيرونى & \\
\hline
\end{tabular}

جدول ^. مقايسه دوبهدوى روش درمان واقعيت مجازى و ذهن آكاهى گذيرش بر كانون توجه

\begin{tabular}{|c|c|c|c|c|c|}
\hline سطح معنادارى & انحراف استاندارد & ميانگين تفاوتها & تروه دوم & كروه اول & متغير \\
\hline$<\cdot / \cdots \cdot 1$ & $\cdot \mid \Delta F$ & T/rA & ذهن آكاهى - يذيرش & واقعيت مجازى & كانون توجه درونى \\
\hline$<\cdot|\cdot \cdot|$ & $\cdot / Q V$ & $-r / 09$ & ذهن آكَاهى - يذيرش & واقعيت مجازى & كانون توجه بيرونى \\
\hline
\end{tabular}

جدول و. تحليل كوواريانس يكىطرفه براى مقايسه اثربخشى درمان مبتنى بر فنآورى واقعيت مجازى و ذهن آكاهى- بذيرش بر

\begin{tabular}{|c|c|c|c|c|c|c|}
\hline اتا & $\mathrm{P}$ & $\mathrm{F}$ & ميانكَين مجذور & $\mathrm{df}$ & مجموع مجذور & منبع تغيير \\
\hline$\cdot / \pi$ & $\cdot / \cdot \wedge$ & $\Delta / \wedge)$ & $194 / 191$ & r & rAV/VAr & مدل تصحيحشده \\
\hline$\cdot 1 \cdot \cdot 1$ &.$/ 94$ & $\cdot 1 \cdot 1$ & - /tak & 1 & - /rat & تعامل \\
\hline$\cdot / 49$ & $\cdot / \cdot r$ & $1 \cdot / A F$ & rql/sభq & 1 & rql/g4q & ييش آزمون \\
\hline \multirow[t]{4}{*}{$\cdot / \cdot r$} & $\cdot / A F$ & $\cdot|\cdot+|$ & $1 / r \Delta F$ & 1 & $1 / r \Delta F$ & كروه \\
\hline & & & GG & Tr & $q \cdots /$ MNF & خطا \\
\hline & & & & r. & G.ror & كل \\
\hline & & & & rq & ITNN/G9V & كل تصحيحشده \\
\hline
\end{tabular}

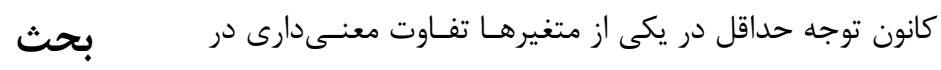
نتايج حاصل از يزوهش نشان داد كه هر دو درمان واقعيت

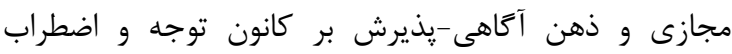

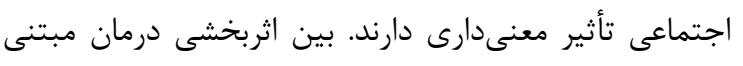

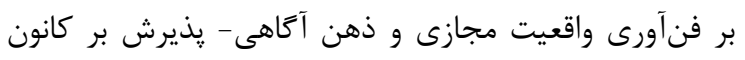

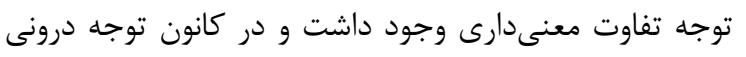

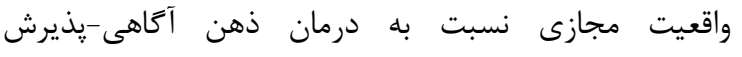

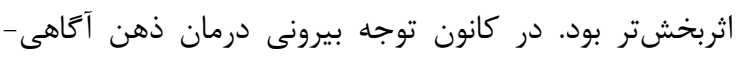

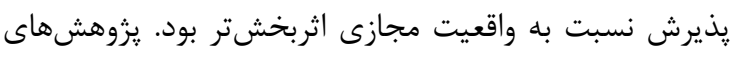

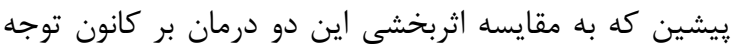

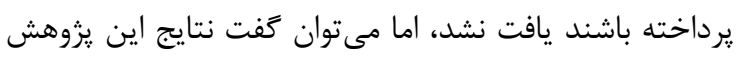

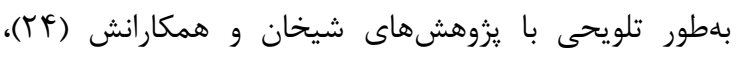

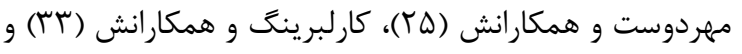

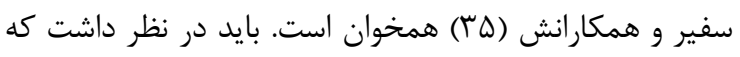

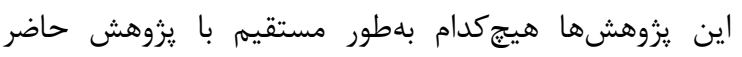

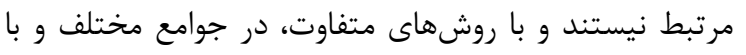

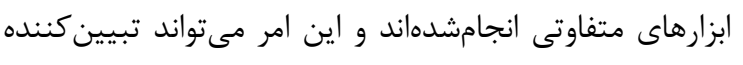

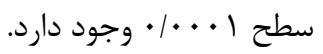

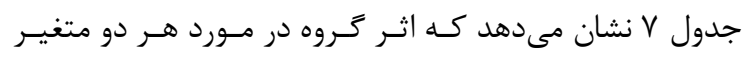

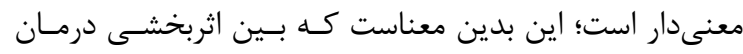

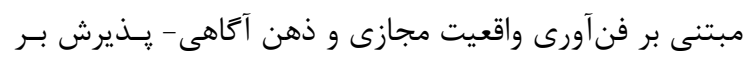

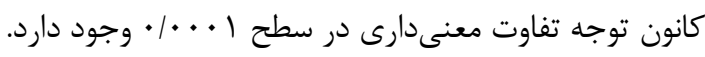

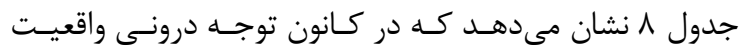

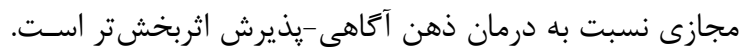

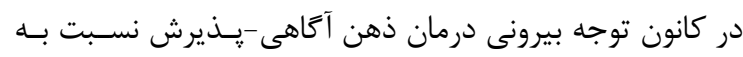

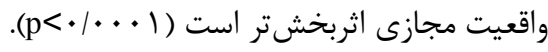

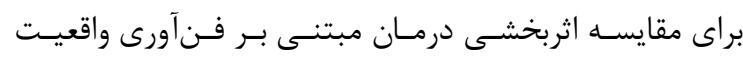

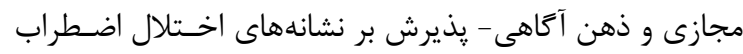

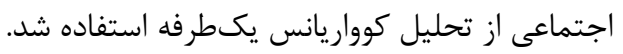

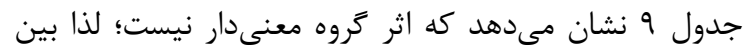

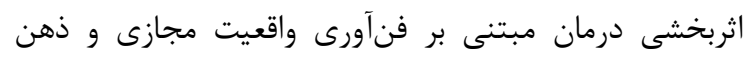

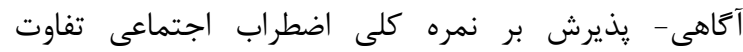

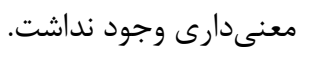

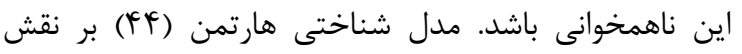




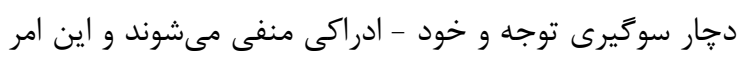

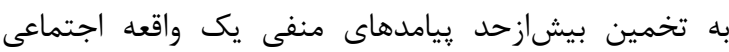

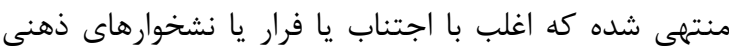

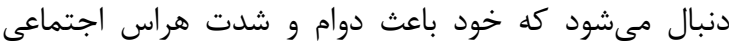
شده و فرد ناخواسته در يك دور باطل كرفتار مىشود (F) (F).

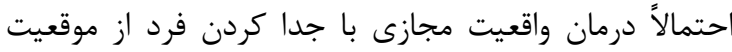
واقعى توازن بين توجه بر خود و بيرون را ايجاد مىكند و واين

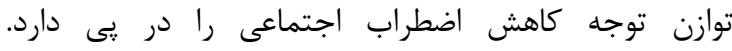
همان كونه كه در بالا ذكر آن رفت، مؤلفان متعددى بيان

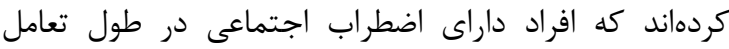

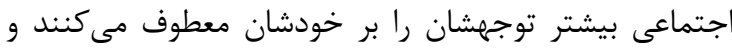
توجه اندكى را صرف كارشان، افراد ديكر و محيط مى كنند بـن

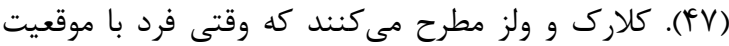
اجتماعى ترسناك وارد مىشود، تغييرى در يردازش بهرئ

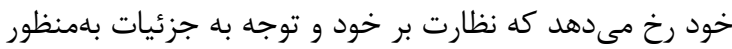

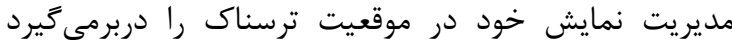

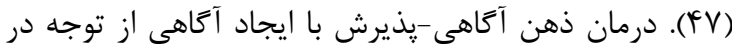

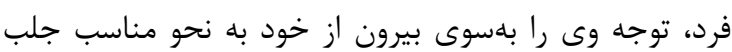

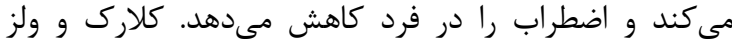
معتقدند افراد مضطرب اجتماعى احساس مىكنيند بهاطور منفى توسط ديخران ارزيابى مىشوند و به بازبينى و مشاهده دقيق خود مىيردازند و بدين ترتيب احساسات منفى در آناني

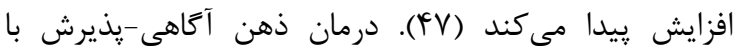
آموزش فاصله كيرى از افكار خودانتقادى و مشاهده افكار بدون

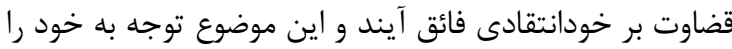

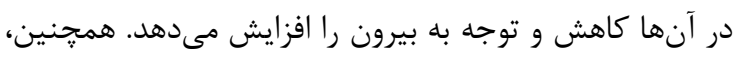

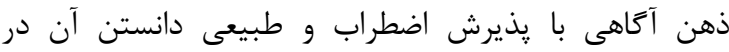

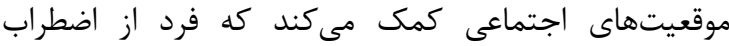

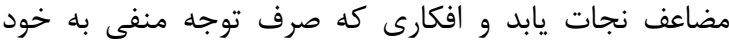
مىشود كاهش يابد. در آموزش ذهن آكاهى فرد مى آموزد كه

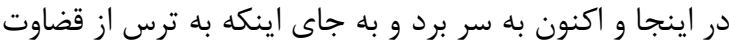

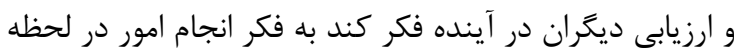

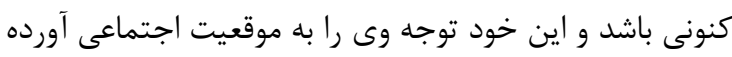
و به مقابله مؤثرتر با موقعيت كمك مى كند (•) (ه). بين اثربخشى درمان مبتنى بر فنآورى واقعيت مجازى و ذهن منابن

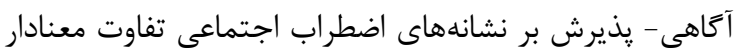

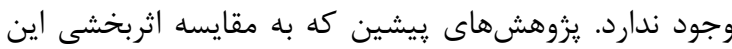

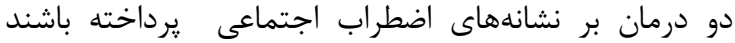

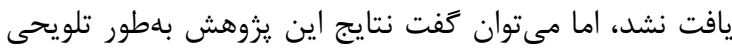

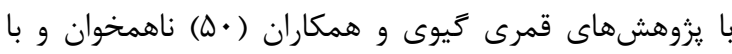

توجه تأكيد فراوانى دارد و معتقد است كه افراد مبتلا به به

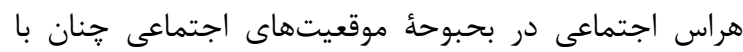
فرآيندهاى متمركز بر خود دركير هستند كه با عملكرد

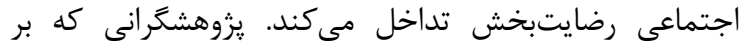
نقش توجه در اختلال اضطراب اجتماعى تأكيددارند بر اين تداني

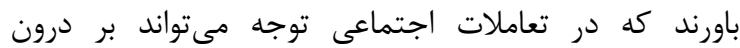

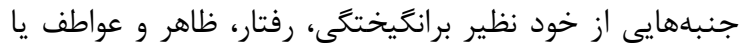
بيرون نظير ديخران، حركات دست يا محيط اطراف متمركز

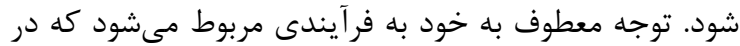
آن توجه بهسوى محركهاى مربوط به خود هدايت مىشود (دهأ). درمان واقعيت مجازى مى تواند با تمرين توجه متمركز بر بيرون (ديخران و محيط) به جاى درون (برانكَيختخى، رفتار، ظاهر و عواطف) اضطراب اجتماعى فرد را كاهش دهد. به بهلاوه،

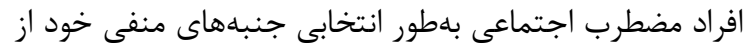

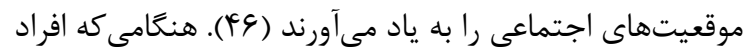
داراى اضطراب اجتماعى در موقعيتهايى اجتماعى قرار

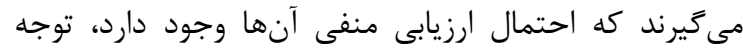

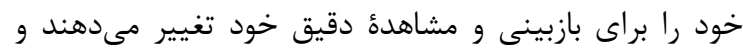
ازاينرو دسترسى به احساسات و افكار منفى در آنها افزايش

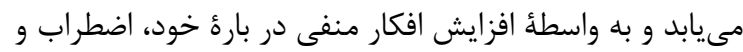

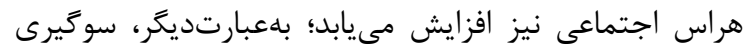

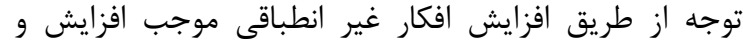

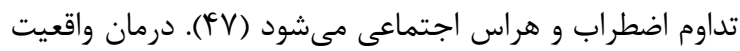

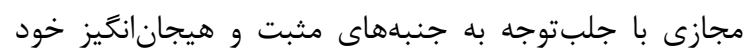
مىتواند توجه را از جنبههاى منفى جدا كند و و به به كاهش

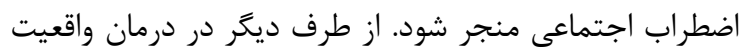

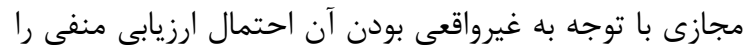
در افراد كاهش مىدهد و اين بلنوبه خود منجر به كاهش افئ افكار و احساسات منفى در مورد خود شده و توجه فرد به جنبه إهاى منفى خود را كاهش و جنبههاى مثبت را افزايش مئدهد همجنين، ولز و متيوز (1) بر اين باورند كه تعامل اجتماعى

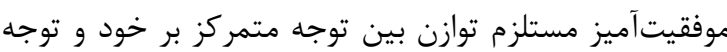

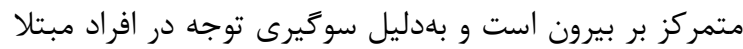
به هراس اجتماعى اين توازن مختل مىشود؛ بنابراين، به نظر مىرسد كه اين افراد در موقعيتهاى اجتماعى توجه متمركز

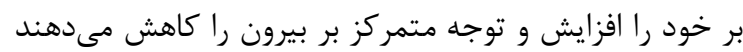

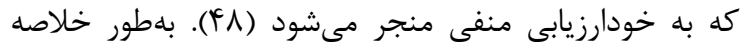

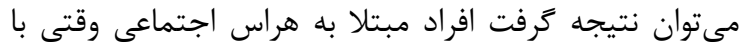

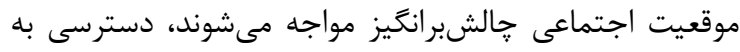

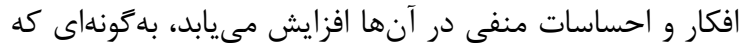


يزوهش حاكى از اين بود كه درمان واقعيت مجازى و يذيرش

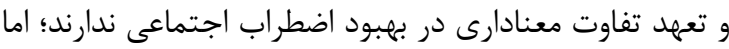

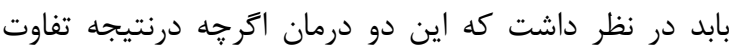

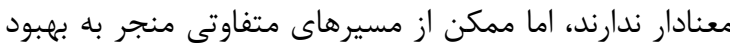

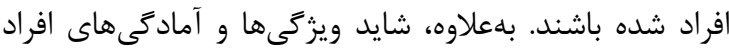
براى اين دو درمان متفاوت باشد و هركدام از اين درمانها

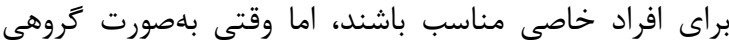
مورد درمان قرار مى كيرند اين تفاوتها ملاحظه نمى إسوند. همجنين، بايد توجه شود كه هركدام از اين درمانها مدركن

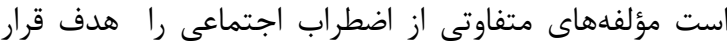
دهند و درنهايت به درمان اختلال منجر شوند. مهمترين محدوديت يزوهش حاضر فقدان كروه كنترل براى مقايسه

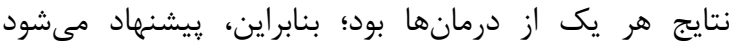
يروهشهاى آينده به مقايسه اين دو درمان با كروه كنترل

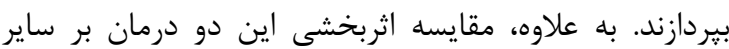

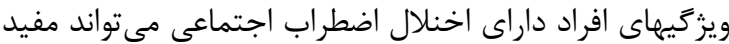

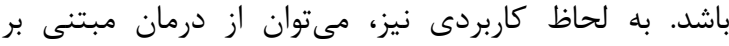

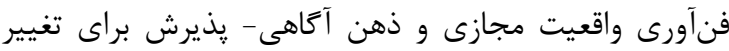
كانون توجه و نيز اضطراب اجتماعى استفاده كرد و در كانون توجه درونى، واقعيت مجازى و در كانون توجه بيرونى درمان

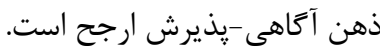

\section{تقدير و تشكر}

در پايان از موسسه تحقيقات علوم رفتارى شناختى سينا كه برنامه كاربردى واقعيت مجازى اضطراب اجتماعى را بهصورت

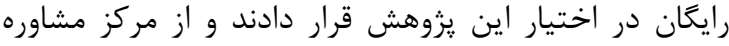

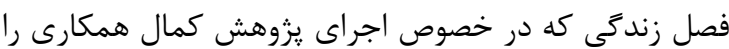

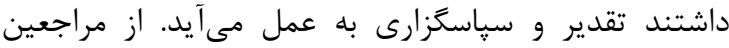

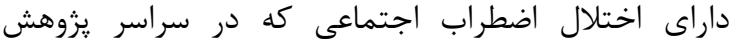

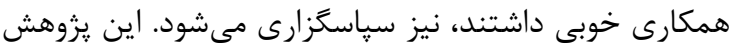

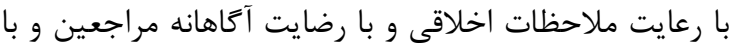

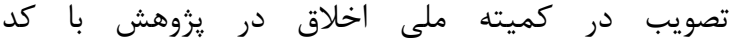
IR.IAU.SHAHROOD.REC.1398.005 صورت يذيرفت.
يزوهشهاى كلدين و همكاران (T9) و هيوته و هيوته (TY) همخوان است.درمان واقعيت مجازى مىتواند با فراهم كردن امكان مواجهه به شرايط شبه واقعى كه در آن ترسى از آن إنى شكست وجود ندارد، اضطراب اجتماعى را كاهش دهد. همجنين وجود عدم ناتوانى و ترس از ناتوانى، احساس كنترل بيشترى در فرد به وجود مى آورد كه اين خود نشانهان آنهاي ضطراب اجتماعى را كاهش مىدهد. طراحى محيط جذاب از

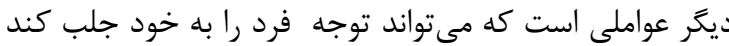
و وى را از افكار منفى را موقعيت نجات دهد و بدين ترتيب

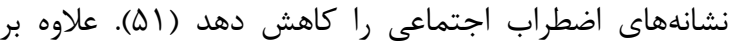

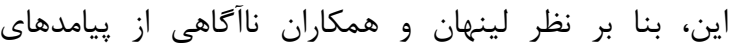

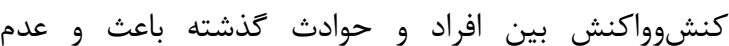
بيشبينى يذيرى آينده منجر به اضطراب اجتماعى مى شود.

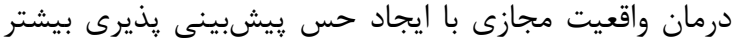

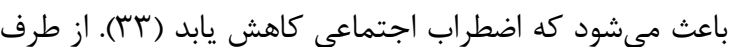
ديخر درمان واقعيت مجازى با ايجاد ماهيت ديدارى و وإنا شنيدارى تازه و هيجانانگيز، تعامل سازنده با دنياى اطراف و دان فقدان محدوديتهاى دنياى واقعى ايجاد خود ينداره مثبت، مشغوليت و دركيرى باعث مىشود كه فرد تسلط بيشترى در موقعيتهاى اجتماعى احساس كند و درنتيجه عملكرد بهترى

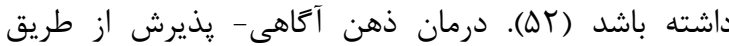

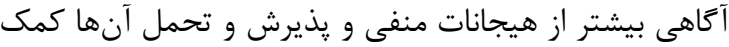
مى كند تا عملكرد فرد در موقعيت اجتماعى بهبود و و اضطراب إنداب

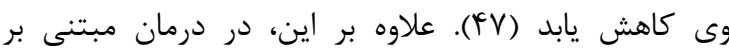

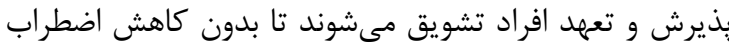

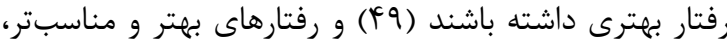

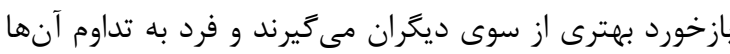

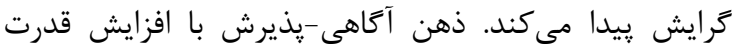

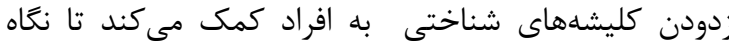

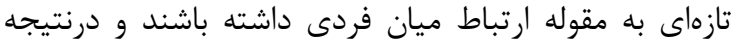

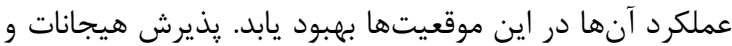

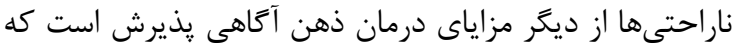

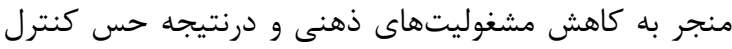
بيشتر روى موقعيت و نيز هيجانات خود شده و عملكرد بهتر

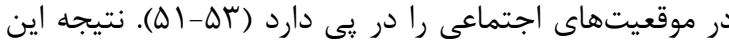

\section{REFERENCES}

1. Ostovar S, Khaier M, Taghavi MR, Eds. Theoretical, research and theraputic bases of social anxiety disorder. Shiraz: Eram press; 2013. [In Persian]

1. Sosic Z, Gieler U, Stangier U. Screening for social phobia in medical in and outpatients with germen version of social phobia Inventory (SPIN). J Anxiety Disord 2008; 849-859. 
2. American Psychiatric Assossiation. Diagnostic and statistical manual for mental disorders. (Fifth Edition) (DSM-V). Seyedmohammadi Y: translator. Tehran: Ravan; 2013. [In Persian]

3. McAleavey AA, Castonguay LG, Goldfried MR. Clinical experiences in conducting cognitivebehavioral therapy for social phobia. J Behav Ther 2014; 45: 21-35.

4. Grant DM, Beck JG. Attentional biases in social anxiety and dysphoria: Does comorbidity make a difference? J Anxiety Disord 2006; 20: 520-529.

5. Hofmann SG, Sawyer AT, Fang A, Asnaani A. Emotion dysregulation model of mood and anxiety disorders. Depr Anxiety 2012; 29: 409-416.

6. Eldar S, Ricon T, Bar-Haim Y. Plasticity in attention: implications for stress response in children. Behav Res Ther 2008; 46: 450-461.

7. Bar-Haim Y, Lamy D, Pergamin L, Bakermans-Kranenburg M, Van Ijzendoorn M. Threat- related attentional bias in anxious and nonanxious individuals: a meta-analytic study. Psychol Bull 2007; 133: 1- 24.

8. Wells A. The attention training technique: theory, effects, and a metacognitive hypothesis on auditory hallucinations. Cogn Behav Pract 2007; 14: 134-8.

9. McEvoy PM, Perini SJ. Cognitive behavioral group therapy for social phobia with or without attention training: a controlled trial. J Anxiety Disord 2009; 23:519-28.

10. Hodson KJ, McManus FV, Clark DM, Doll H. Can Clark and Wells' (1995) cognitive model of social phobia be applied to young people? Behav Cogn Psychother 2008; 36: 449-461.

11. Taylor S. Meta-analysis of cognitive-behavioral treatments for social phobia. J Behav Ther Exp Psychiatry 1996; 27: 1-9.

12. Hofmann SG, Sawyer AT, Fang A, Asnaani A. Emotion dysregulation model of mood and anxiety disorders. Depress Anxiety 2012; 29: 409-416.

13. Burdea G, Ed. Virtual reality systems and applications electro. International Conference, Short Course. NJ: Edison Helen Valach; 1993.

14. Emmelkamp PMG, Krijn M, Hulsboseh AM, Devries S, Schuemie MJ, Vander Mast CA. Virtual reality treatment versus exposure on vivo: a comparative Evaluation in Acrophobia. Behav Res Ther 2002;5: 509-516.

15. Eslami P, Monshei GH, Hajebrahimi Z. Effectiveness of virtual reality on reduction fear of flying among individuals with fear of flying. Clin Psychol 2014; 13: 44-62. [In Persian]

16. Soleimani M, Ahmadi K, Ed. The basics and practice of virtual reality therapy. Tehran: Sina Press; 2016. [In Persian]

17. Ost LG. Efficacy of the third wave of behavioral therapies: a systematic review and meta-analysis. Behav Res Ther 2008; 46: 296-321.

18. Hayes SC, Luoma JB, Bond FW, Masuda A, Lillis J. Acceptance and commitment therapy: model, processes and outcomes. Behav Res Ther 2006; 44: 1-25.

19. Nazemi H, Najafi M, Makvand Hosseini S, Maleki A, Rahimian Boogar E. Effectiveness of virtual reality exposure therapy on reduction avoidance and social distress symptoms among individuals with social anxiety disorder. Bebav Sci Res 2018; 16: 389-399. [In Persian]

20. Ostadian Khani z, Fadaei Moghadam M. Effectiveness of group acceptance and commitment therapy on social adjustment and social phobia of physiologic disabled. Rehabilitation 2016; 18: 63-72. [In Persian]

21. Soleimani M, Ahmadi K, Mohamadi A. Virtual reality exposure therapy in anxiety disorders and PTSD: A systematic review of litrarture. Bebav Sci Res 2016; 14: 111-124. [In Persian]

22. Shabani J, Masdari M. Effectiveness of training mindfulness-based cognitive therapy in reducing social anxiety disorder among first high school female students. Cognitive Journal of Psychology and Psychiatry 2016; 12-27. [In Persian]

23. Sheykhan R, Mohammadkhani S, Hasanabadi H R. The effect of the group training of the attention training technique on anxiety, self-focused attention and metaworries in socially anxious adolescents. JCP 2013; 1:33-45. [In Persian]

24. Mehrdoost Z, Neshatdoost HT, Abedi A. Effectiveness acceptance and commitment therapy on reducing selffocused attention and modification self-efficacy beliefs. Psychological Methods and Models 2014; 3: 67-71. [In Persian] 
25. Bakhtyarpour S, Heidari A, Alipoor Kodadadi S. relationship between attention bias and general self-efficacy with social anxiety among female students. Woman and Culture 2012; 3: 71-85. [In Persian]

26. Taherifar Z, Fata L, Gharaei B. The pattern of prediction in students based on cognitive-behavioral factors. Iranian J Psychiatry Clin Psychol 2010; 16: 33-45.

27. Khayyer M, Ostovar S, Latifian M, Taghavi MR, Samani S. The study of mediating effects of self-focused attention and social self-efficacy on links between social anxiety and judgment biases. J Psychiatry Clin Psychol 2008; 14: 24-32.

28. Goldin PR, Morrison AS, Jazaieri H, Heimberg RG, Gross JJ. Trajectories of social anxiety, cognitive reappraisal, and mindfulness during an RCT of CBGT versus MBSR for social anxiety disorder. Behav Res Ther 2017; 97:1-13.

29. Kim HE, Hong YJ, Kim MK, Jung YH, Kyeong S, Kim JJ. Effectiveness of self-training using the mobile-based virtual reality program in patients with social anxiety disorder. Comput Human Behav 2017; 73: 614-619.

30. Boll S, Bartholomaeus M, Peter U, Lupke U, Gamer M. Attentional mechanisms of social perception are biased in sicail phobia. J Anxiety Disord 2016; 40: 83-93.

31. Yuen EK, Herbert JD, Forman EM, Goetter EM, Comer R, Bradley JC. Treatment of social anxiety disorder using online virtual environments in second life. Behav Ther 2013; 44:51-61.

32. Carlbring P, Apelstrand M, Sehlin H, Amir N, Rousseau A, Hofmann SG, et al. Internet-delivered attention bias modification training in individuals with social anxiety disorder - a double blind randomized controlled trial. BMC Psychiatry 2012; 12: 1-9.

33. Heuett BL, Heuett AB. Virtual reality therapy: a means of reducing public speaking anxiety. Int J Humanit Soc 2011; 1: 1-6.

34. Safir MP, Wallach HS, Bar-Zvi M. Virtual reality cognitive-behavior therapy for public speaking anxiety: one-year follow-up. Behav Modif 2012; 36: 235-246.

35. Dalrymple KL, Herbert JD. Acceptance and commitment therapy for generalized social anxiety disorder: a pilot study. Behav Modific 2007; 31: 543-568.

36. Woody SR, Chambless DL, Glass CR. Self-focused attention in the treatment of social phobia. Behav Res Ther 1997;35: 117-129.

37. Connor KM, Davidson JRT, Churchil LR, Sherwood A, Foa G, Wisler RH. Psychometric properties of the social phobia inventory (SpIN): new self-rating scale. Br J Psychiatry 2000; 176: 379-386.

38. Hasavan Amoozade M, Hasavan Amoozade A, Ghadampour M. Prediction social phobia symptoms (fear, avoidance and physiologic distress) based on maladjustment primary shemas. Psychol Res 2014;8: 94-115.

39. North Mm, North SM, Coble JR. Virtual reality therapy: An effective treatment for the fear of public speaking. International Journal of Virtual Reality 2015; 3: 1-6.

40. Kocovski NL, Fleming JE, Rector NA. Mindfulness and acceptance-based group therapy for social anxiety disorder: an open trial. Cogn Behav Pract 2009; 16: 276-289.

41. Segal ZV, Williams JMG, Teasdale JD. Mindfulness-based cognitive therapy for depression: a new approach to preventing relapse. New York: The Guilford Press; 2002.

42. Harris R. ACT made simple: an easy-to-read primer on acceptance and commitment therapy. New York: Harbinger Publications; 2009.

43. Raoofi Ahmad R, Tatkhan M, Ghorban Shiroodi S, Nouzari M. Relationship between attention bias and self-efficacy with social anxiety among female high school students. Soc Psychol Res 2011; 2: 27-38.

44. Bogels SM, Mansell w. Attention process in the maintenance and treatment of social phobia: Hyper vigilance, avoidance and self-focused attention. Clin Psychol Res 2004; 24: 827-856.

45. Hertel PT, Brozovich F, Joormann J, Gotlib IH. Bias in interpretation and memory in generalized social phobia. J Abnorm Psychol 2008; 117: 278-288.

46. Clark D, Wells A. A cognitive model of social phobia. In: social phobia: diagnosis, assessment and treatment. New York: Guilford Press; 1995.

47. Pineles SL, Mineka S. Attentional biases to internal and external sources of potential threat in social anxiety. J Abnorm Psychol 2005; 114: 314-318.

48. Hayes SC, Stroshal KD, Wilson KG, Bissett RT, Pistorello J, Toarmino D, et al. Measuring experiential avoidance: a preliminary test of a working model. Psycholog Rep 2004; 54: 553-578. 
49. Ghamari Givi H, Agh AS, Mehrabadi S. Comparing cognitive behavior therapy based on computer with clinical therapy on social anxiety disorder. Couns Psychother Res 2011; 4: 91-110.

50. Reid DT. Benefits of a virtual play rehabilitation environment for children with cerebral palsy on participants of self-efficacy: a pilot study. Pediatr Rehabil 2002; 5: 141-148.

51. Linehan MM, Armstrong HE, Suarez A, Allmon D. Cognitive behavioral treatment of chronically parasuicidal borderline patients. Arch Gen Psychiatry 1991; 48: 1060-1065.

52. Costa RT, Carvalho, MR, Nardi AE. Virtual reality exposure therapy in the treatment of driving phobia teor. EPESQ Brasilia 2010; 26: 131-137.

53. Emmelkamp PMG, Meyerbröker K, Morina N. Virtual reality therapy in social anxiety disorder. Curr Psychiatry Rep 2020;22:32. 